\title{
Taxonomy, annotated new records and a checklist of Mymaridae (Hymenoptera) of Finland, with description of a new species of Eustochus
}

\author{
Serguei V. TRIAPITSYN ${ }^{1)}$, Martti KOPONEN²), Veli VIKBERG ${ }^{3)} \&$ Gergely VÁRKONYI ${ }^{4)}$ \\ ${ }^{1)}$ Entomology Research Museum, Department of Entomology, University of California, Riverside, California, 92521, USA; \\ e-mail: serguei.triapitsyn@ucr.edu \\ 2) Tuoppitie 5 C, FI-50160, Mikkeli, Finland; e-mail: mar.koponen@surffi.fi \\ ${ }^{3)}$ Liinalammintie 11 as. 6, FI-14200, Turenki, Finland; e-mail: veli.vikberg@pp.inet.fi \\ 4) Finnish Environment Institute SYKE, Biodiversity Centre, FI-88900, Kuhmo, Finland; e-mail: gergely.varkonyi@ymparisto.fi
}

\begin{abstract}
Accepted:
$5^{\text {th }}$ October 2020

Published online: $6^{\text {th }}$ November 2020
\end{abstract}

\begin{abstract}
A taxonomic account and an annotated checklist of the Finnish Mymaridae (Hymenoptera: Chalcidoidea) are given, comprising 85 named species in 19 genera. Among them 2 genera, Dicopus Enock, 1909 and Stethynium Enock, 1909, 1 subgenus, Anagrus (Paranagrus Perkins, 1905), and the following 25 species represent new records for Finland: Anagrus (Anagrus) avalae Soyka, 1956, A. (Anagrus) bakkendorfi Soyka, 1946, A. (Anagrus) ensifer Debauche, 1948, A. (Anagrus) nigriceps (Smits van Burgst, 1914), A. (Anagrus) obscurus Förster, 1861, A. (Anagrus) parvus Soyka, 1956, A. (Anagrus) subfuscus Foerster, 1847, A. (Paranagrus) optabilis (Perkins, 1905), Anaphes (Anaphes) stygius Debauche, 1948, Camptoptera magna Soyka, 1946, Cleruchus megatrichus Novicky, 1965, C. taktochno Triapitsyn, 2014, Cosmocomoidea oxypygus (Foerster, 1856), C. tremulae (Bakkendorf, 1934), Dicopus minutissimus Enock, 1909, D. moscovit Triapitsyn, 2015, Gonatocerus aegyptiacus Soyka, 1950, Lymaenon aureus (Girault, 1911), L. longior (Soyka, 1946), Polynema flavipes Walker, 1846, P. fuscipes Haliday, 1833, P. pusilloides Debauche, 1948, P. valkenburgense Soyka, 1931, P. vitripenne (Foerster, 1847), and Stethynium triclavatum Enock, 1909. New distributional records and taxonomic notes on some genera and species are also provided. Caraphractus Walker, 1846, syn. nov. is synonymized with Eustochus Haliday, 1833 and treated as its subgenus, E. (Caraphractus), stat. revid., and its type species Caraphractus cinctus Walker, 1846 is transferred to Eustochus as Eustochus (Caraphractus) cinctus (Walker, 1846), comb. nov. Eustochus (Eustochus) koponeni Triapitsyn, sp. nov. is described from Finland and Germany. Lymaenon gracilentus (Hellén, 1974), stat. restit. is resurrected as a valid species from the previous synonymy with Lymaenon aureus and redescribed. The previously unknown male of Alaptus schmitzi Soyka, 1939 is described. Polynema depressicollis Hellén, 1974, syn. nov., is synonymized with Polynema (Doriclytus) vitripenne. Anagrus (Paranagrus) optabilis is newly recorded from the Canary Islands and Madeira, and Cleruchus megatrichus is for the first time reported from France.
\end{abstract}

Key words. Hymenoptera, Chalcidoidea, Mymaridae, fairyfly, taxonomy, synonymy, egg parasitoid, biodiversity, checklist, Finland, Palaearctic Region

Zoobank: http://zoobank.org/urn:1sid:zoobank.org:pub:659934F0-6B73-4571-8ADA-5E14CD3669EC

(C) 2020 The Authors. This work is licensed under the Creative Commons Attribution-NonCommercial-NoDerivs 3.0 Licence.

\section{Introduction}

The Finnish fauna of Mymaridae (Hymenoptera: Chalcidoidea), commonly known as mymarids or fairyflies, is typical for the northwestern Palaearctic Region and as such is relatively species poor. Yet, it is still very interesting by being one of the best known for a single European country, quite comparable to the fauna of the United Kingdom which is generally well known (NOYES 
2019) but has been studied for a much longer time. That is largely due to the earlier work of Wolter Hellén who based his review of the Finnish Mymaridae (HeLléN 1974) on his own collection, most specimens in which were likely captured by sweep netting, albeit it was relatively small (about two full drawers). Even though his summary is nowadays somewhat outdated, it provided a good basis for the present study. Additional, fairly limited accounts of the species in a few mymarid genera were made by Soyka (1949, 1950, 1955, 1956a, b); however, most (if not all) of the species he described from Finland in Polynema Haliday, 1833 would eventually be proven to be synonyms of the earlier described taxa, as were his species in another large genus, Anaphes Haliday, 1833 (HuBER \& Thuróczy 2018). For the time being, however, until the European species of Polynema are thoroughly revised based on type and other material (S. V. Triapitsyn, in preparation), we include them as valid taxa. Also, unlike for some other mymarid genera, in the checklist the species of Polynema are not listed in the currently recognized subgenera because subgeneric placement of some of them is yet to be clarified. Besides, the subgeneric concepts within Polynema sensu lato are likely to be significantly changed (TRIAPITSYN \& FIDALGO 2006).

More recent extensive, systematic collections of Finnish mymarids have been made mainly by the second and third authors since the 1970s, primarily by sweep netting. Very few were also reared from plant substrates by the third author.

Finnish Mymaridae of both sexes can be determined to genus using the key in SAmKoví et al. (2020), while the earlier keys in SCHAUFF (1984), TRIAPITSYN \& HUBER (2000), and Pricop (2013) can also be used to identify most genera occurring in Finland (the latter key applies to females only). The genera of Gonatocerini can be also sorted out using the key in HUBER (2015).

Hosts of the Finnish Mymaridae have been largely unknown, except for a Polynema sp. which was reported

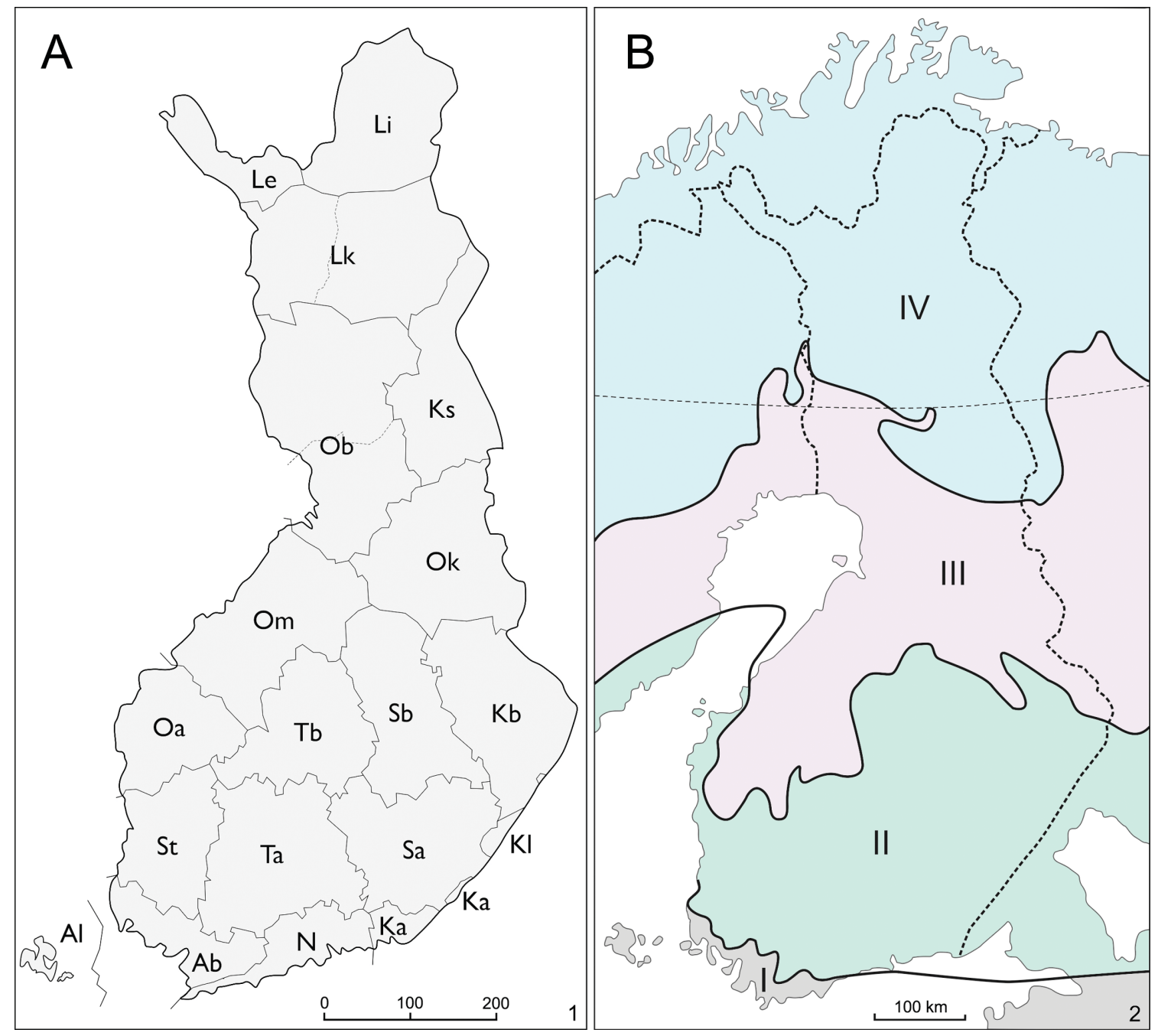

Fig. 1. Maps of Finland: $\mathrm{A}$ - natural history provinces of Finland $(\mathrm{Ab}=$ Regio aboënsis [Varsinais-Suomi], $\mathrm{Al}=\mathrm{Alandia}[\mathrm{Ahvenanmaa}$, Ka $=\mathrm{Karelia}$ australis [Etelä-Karjala], Kb = Karelia borealis [Pohjois-Karjala], Kl = Karelia ladogensis [Laatokan Karjala], Ks = Regio kuusamoënsis [Kuusamo], $\mathrm{Le}=$ Lapponia enontekiensis [Enontekiön Lappi], Li = Lapponia inarensis [Inarin Lappi], Lk = Lapponia kemensis [Kemin Lappi] with western and eastern subdivisions Lkoc and Lkor, $\mathrm{N}=$ Nylandia [Uusimaa], Oa = Ostrobottnia australis [Etelä-Pohjanmaa], Ob = Ostrobottnia borealis [Pohjois-Pohjanmaa] with northern and southern subdivisions Obb and Oba, Ok = Ostrobottnia kajanensis [Kainuu], Om = Ostrobottnia media [Keski-Pohjanmaa], $\mathrm{Sa}=$ Savonia australis [Etelä-Savo], $\mathrm{Sb}=$ Savonia borealis [Pohjois-Savo], $\mathrm{St}=$ Satakunta, $\mathrm{Ta}=$ Tavastia australis [Etelä-Häme], $\mathrm{Tb}=\mathrm{Tavastia}$ borealis [Pohjois-Häme]. B - forest vegetation zones of Finland according to AHTI et al. (1968): I (grey) = hemiboreal, II (light green) = southern boreal, III $($ pink $)=$ middle boreal, IV (light blue) $=$ northern boreal. 
to be an egg parasitoid of the green leafhopper, Cicadella viridis (Linnaeus, 1758) (Hemiptera: Cicadellidae), in Hyvinkää (Uusimaa) on Betula pendula (HuLdÉN 1984). Unfortunately, we were unable to find voucher specimens of this study to identify them to species and also to check correctness of the generic identification because this record seems to be rather odd: normally, eggs of $C$. viridis are parasitized by members of Anagrus Haliday, 1833 and Gonatocerus Nees ab Esenbeck, 1834 (TRIAPITSYN 2013, 2015b).

\section{Material and methods}

Repositories of the specimens are as follows:

BMNH The Natural History Museum, London, England, United Kingdom;

CNC Canadian National Collection of Insects, Arachnids and Nematodes, Ottawa, Ontario, Canada;

FMNH Zoological Museum, Finnish Museum of Natural History, University of Helsinki, Helsinki, Finland;

ISNB Institut Royal des Sciences Naturelles de Belgique, Brussels, Belgium;

NMEG Naturkundemuseum Erfurt, Erfurt, Thuringia, Germany;

UCRC Entomology Research Museum, Department of Entomology, University of California, Riverside, California, USA;

VVCT Veli Vikberg private collection, Turenki, Finland.

Species occurrence records given in square brackets refer to those from pre-WWII Finnish territories that are now part of Russia. Text put in square brackets after locality names or biotope categories are translations of label text written in Finnish or Swedish.

Terms used for morphological features are mostly those of GIBSON (1997). All measurements were taken from the slide-mounted specimens, unless stated otherwi$\mathrm{se}$, and are given in $\mathrm{mm}$, as length or, for the wings, as length : width.

The following abbreviations of morphological terms are used:

F funicle segment of the female antenna or flagellomere of the male antenna;

mps multiporous plate sensillum or sensilla on the antennal flagellar segments (= longitudinal sensillum or sensilla or sensory ridge(s) of other authors).

Specimens collected by M. Koponen were mounted air-dried on points or cards, and labeled; these have been all donated to FMNH. Specimens collected by V. Vikberg (all in VVCT) were selectively point-mounted (air-dried) but remain mostly spread on paper in Petri dishes and those were not examined and thus remain unidentified. About 5000 specimens from FMNH, most of which were collected by M. Koponen, were sent on loans to the first author for sorting and identification. These have been all identified at least to genus, and many (except for some Anagrus as well as most Anaphes and many Polynema) were also identified to species. Those of Anaphes need to be slide-mounted first (females only, because most males cannot be positively identified even to subgenus). The remaining specimens of Mymaridae in FMNH (including the entire collection of W. Hellén) and VVCT were examined and identified by S. V. Triapitsyn during a visit to those collections in Helsinki and Turenki, respectively, in July 2017. More than 300 selected specimens of several genera (mostly of Anagrus and Polynema) were slide-mounted at UCRC by Vladimir V. Berezovskiy to facilitate identification. Most of Ooctonus Haliday, 1833 (over 2200 specimens) were identified mainly by M. Koponen using the key in TRIAPITSYN (2010) (KoPONEN et al. 2019).

For the new distributional records in the different biological provinces of Finland, their mapped abbreviations (Fig. 1) follow those in KHALAIM \& VÁRKONYI (2018: 155, fig. 2), while the archaic but still broadly used locality grids, with which entomologists outside of Finland are hardly familiar with (as numerical xxxx:xxxx), are indicated according to HEIKINHEIMO \& RAATIKAINEN (1971). Because many thousands of Finnish Mymaridae in FMNH and VVCT (almost all specimens collected after W. Hellén, except for a few recently captured by J. Paukkunen, are labeled this way, Hellén's containing brief information only on a geographical locality as it was known at that time), converting these to more precise and user friendly georeferenced localities was not feasible.

\section{Taxa new for Finland and new distribution records}

\section{Alaptus fusculus Walker, 1846}

Material examined. $\boldsymbol{N}$ : Hanko (labeled as Hangö), 1931, W. Hellén (3 우, FMNH). Ta: Janakkala, Hangastenmäki (6755:3369), river shore, 15.vii.1978, V. Vikberg (1 , , VVCT).

Distribution. Palaearctic (Belgium, Bulgaria, China, Denmark, Finland, France, Germany, Greece, Ireland, Italy, Kyrgyzstan, Madeira, Netherlands, North Macedonia, Poland, Romania, Russia, Spain, United Kingdom), Nearctic (Canada, USA), and Neotropical (Argentina) Regions (TRIAPITSYN 2017).

\section{Alaptus minimus Westwood, 1839}

Material examined. Al: Jomala, Möckelö, 25.vii.1926, W. Hellén (1 + FMNH). $\mathbf{N}$ : Nurmijärvi, Kiljava, Vaaksi (6711:3373), ash forest, 17.viii.1995, M. Koponen (3 우, FMNH). Sa: Mikkeli (6840:3507), 25.viii.1996, M. Koponen (1 , FMNH). Ta: Janakkala, V. Vikberg: Kalpalinna (6760:3370), 27.vii.1977 (2 우, VVCT); Viralanjärvi, 24.ix.1978 (1 q, VVCT). Kb: Joensuu, 24.viii.1969, V. Vikberg, on window $(1$,, VVT)

Distribution. Palaearctic (Austria, Belgium, Bulgaria, Czech Republic, Denmark, Egypt, Estonia, Finland, France, Georgia, Germany, Greece, Italy, Kyrgyzstan, Madeira, Netherlands, North Macedonia, Poland, Romania, Russia, Serbia, Spain, Switzerland, United Kingdom), Afrotropical (Cape Verde), Australasian (Australia and New Zealand), Nearctic (Canada and USA), Neotropical (Argentina, Puerto Rico), and Oriental (Pakistan) Regions (TRIAPITSYN 2017; SAMKová et al. 2020).

\section{Alaptus schmitzi Soyka, 1939 (Fig. 2)}

Material examined. $N$ : Nurmijärvi (6710:3381), 9.viii.1994, M. Koponen $(1 \hat{\partial}, \mathrm{FMNH})$.

Description of male. The male (previously unknown for this species) is described here from one specimen 


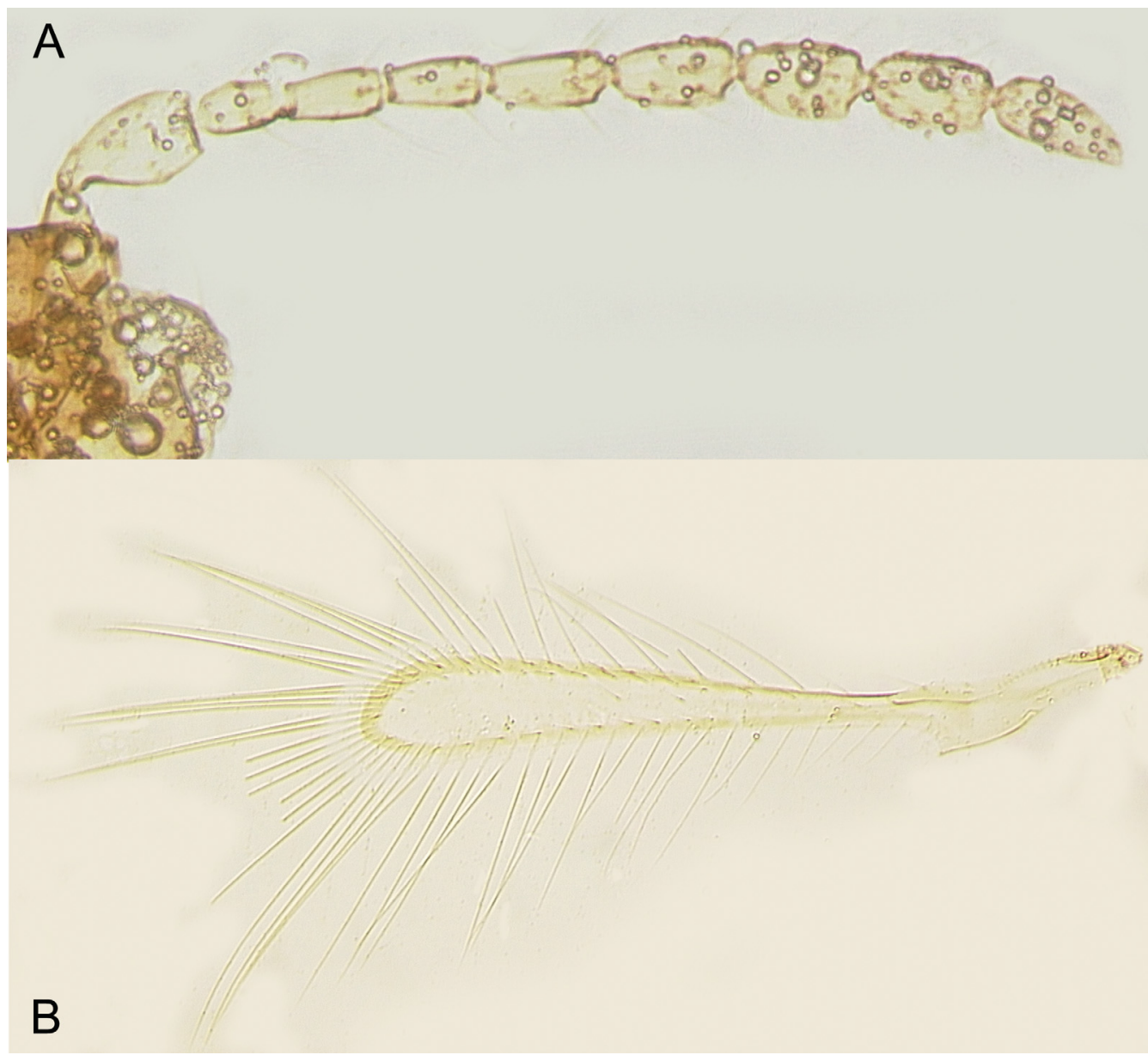

Fig. 2. Alaptus schmitzi Soyka, 1939, male (Nurmijärvi, Uusimaa, Finland): A - antenna; B - fore wing.

from Finland, which was identified by S. V. Triapitsyn in 2017 and then slide-mounted in Canada balsam by V. V. Berezovskiy. Body length of the air-dried, point-mounted specimen prior to slide-mounting was $0.25 \mathrm{~mm}$ (of the same but slide-mounted specimen $0.34 \mathrm{~mm}$ ). Body black; scape, pedicel, F1 and most leg segments light brown; remainder of antennal segments and coxae brown. Similar to female as redescribed in detail by TRIAPITSYN (2017) except for normal sexually dimorphic features of antenna (Fig. 2A) and genitalia. Scape minus small radicle about 3 times as long as wide; all flagellar segments at least a little shorter than pedicel except F8 about as long as pedicel. Fore wing (Fig. 2B) 8.1 times as long as wide, with 1 or 2 setae in the middle of disc; hind wing about 16 times as long as wide.

Distribution. Palaearctic Region (Bulgaria, China, Finland, Norway, Poland, Russia, United Kingdom) (TRIAPITSYN 2017).

\section{Anagrus (Anagrus) avalae Soyka, 1956}

Material examined. N: Nurmijärvi, M. Koponen (6707:3381), 6.x.1996, riverside (1 \&, FMNH). Rajamäki (6715:3376), 17.vii.1981 (1 q, FMNH). Nukari (6714:3385), 5.viii.1990, riverside (1 ㅇ, FMNH). Siuntio, Pikkala (6668:3349), 30.viii.1981, M. Koponen (1 , FMNH).

Distribution. Palaearctic (Belgium, Bulgaria, France, Germany, Greece, Iran, Italy, Japan, Netherlands, Russia, Serbia, Sweden, United Kingdom), Australasian (Australia, New Zealand), Nearctic (Canada, USA), and Neotropical
(Chile) Regions (Triapitsyn 2015b; Triapitsyn et al. 2020a). New species record for Finland.

\section{Anagrus (Anagrus) bakkendorfi Soyka, 1946}

Material examined. $N$ : Nurmijärvi (6715:3376), 18.viii.1981, M. Koponen $(1$ \%, FMNH).

Distribution. Palaearctic Region (France, Germany, Netherlands, Poland, Romania, Spain, United Kingdom) (TRIAPITSYN 2015b). New species record for Finland.

\section{Anagrus (Anagrus) ensifer Debauche, 1948}

Material examined. Sa: Mikkeli, Otava (6835:3503), 18.viii.2008, M. Koponen (1 9 , FMNH); Tusku (6843:3512), 18.vii.2009, M. Koponen (1 + , FMNH). Kb: Tohmajärvi, Vinska, Anttila (6908:3660), 18.vii.1982, M. Koponen (1 \&, FMNH). Uukuniemi (6852:3655), 24.vi.1983, M. Pulkkinen (1 , FMNH). Lkor: Savukoski, UKK park, Jaurujoki, 5.vi.-1. vii.2014, pitfall traps, gravel bank, J. Salmela (1 \&, FMNH).

Distribution. Palaearctic Region (Belgium, Denmark, France, Germany, Greece, Italy, Russia, Sweden, United Kingdom) (TRIAPITSYN 2015b). New species record for Finland.

\section{Anagrus (Anagrus) nigriceps (Smits van Burgst, 1914)}

Material examined. $\boldsymbol{N}$ : Helsinki, M. Koponen: Viikki (6680:3390), 12.viii.1980 (1 q, FMNH); 21.viii.1980 (1 o, FMNH). Inkoo 
(6664:3335), 30.viii.1981, M. Koponen (1 q, FMNH). Lapinjärvi (6723:3455), 16.viii.1981, meadow by shore, M. Koponen (1 q, FMNH). Nurmijärvi, M. Koponen: Nummenpää, 1.ix.1990 (1 \&, FMNH); Teponlampi (6702:3378), 18.vii.1992 (1 ㅇ, FMNH); (6708:3376), 8.viii.1986 (1 ๆ, FMNH); Ylöstalon forest (6705:3380), 23.viii.1992 (1 , FMNH); Kiljava (6712:3373), 23.vi.1987 (1 q, FMNH), 25.vii.1992 (1 q, FMNH). Siuntio, Pikkala (6668:3349), 30.viii.1981, M. Koponen (1 क, FMNH). St: Kokemäki, Peipohja, 29.v.1962, suction trap, O. Heikinheimo (1 ㅇ, FMNH). Ta: Jämsä, Kauranoro (6853:3412), 29.viii.1991, M. Koponen

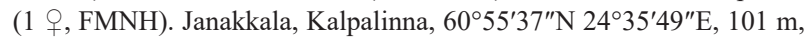
8.vii.2017, S. V. Triapitsyn \& V. Vikberg (1 q, UCRC). Sa: Mikkeli [rural municipality], M. Koponen: Soikkala (6830:3501), 27.vi.1992 (1 + , FMNH); Majalahdentie (6840:3506), 2.viii.1996 (1 ㅇ, FMNH). Ristiina, Ylölänkylä, Alatalo (6826:3502), M. Koponen: 31.viii.1985 (1 ㅇ, FMNH), 21.vii.1989 (1 9, FMNH). Sb: Maaninka, O. Heikinkeimo, suction trap: 19.viii.1962 (1 q, FMNH), 7.ix.1962 (1 q, FMNH), 8.ix.1962 (1 q, FMNH). Om: Alajärvi (6991:3334), 1.viii.1995, M. Koponen (1 +, FMNH). Oba: Ylikiiminki (7232:3461), 6.vii.2000, M. Koponen (1 , FMNH). Ks: Kuusamo, Iso-Kuusikko (7371:3609), 3.vii.1998, M. Koponen (1 9, FMNH)

Distribution. Palaearctic (Austria, Belgium, Bulgaria, China, France, Germany, Greece, Iran, Ireland, Israel, Italy, Kyrgyzstan, Netherlands, Romania, Russia, Spain, Sweden, United Kingdom) and Nearctic (Greenland, USA) Regions (Triapitsyn 2015b). New species record for Finland.

\section{Anagrus (Anagrus) obscurus Förster, 1861}

Material examined. $N$ : Nurmijärvi (6707:3381), 6.x.1996, riverside, M. Koponen (1 \&, FMNH). Sipoo, Östersundom (6684:3400), 26.ix.1985, M. Koponen (1 9, FMNH). Sa: Mikkeli [rural municipality], Hietala (6830:3501), 17.viii.1980, M. Koponen (1 q, FMNH). Ristiina, Ylölänkylä, Alatalo (6826:3502), 2.viii.1981, M. Koponen (1,+ FMNH). Oa: Ilmajoki, Hiidenhaudanmaa (6970:3263), 9.vii.1999, M. Koponen (1 9, FMNH). Le: Enontekiö, Hetta (7592:3360), 3.vii.1982, M. Koponen $(1$ q, FMNH).

Distribution. Palaearctic Region (Austria, Bulgaria, Greece, Italy, Kyrgyzstan, North Macedonia, Republic of Korea, Russia, Spain, Switzerland, United Kingdom) (TRIAPITSYN 2015b). New species record for Finland.

\section{Anagrus (Anagrus) parvus Soyka, 1956}

Material examined. $\boldsymbol{A} \boldsymbol{b}$ : Turku, Paattinen (6727:3245), 24.v.1998, M. Koponen (1 9, FMNH). N: Nurmijärvi, M. Koponen: (6708:3382), riverside, 17.v.1998 (1 ․, FMNH); Ruostesuo (6712:3381), 9.viii.1992 (1 ㅇ, FMNH). Porvoo [rural municipality], Sannäs (6690:3431), 3.vi.1982, M. Koponen (1 , , FMNH). Siuntio, Pikkala (6668:3349), 30.viii.1981, M. Koponen (1 ô, FMNH). Ta: Hattula, Parola (6774:3356), 22.viii.1981, railway trackside, M. Koponen (1 9, FMNH). Sa: Mikkeli [rural municipality], Majalahdentie (6840:3506), 2.viii.1996, M. Koponen (1 §, FMNH). Oa: Ilmajoki, Hiidenhaudanmaa (6970:3263), 9.vii.1999, M. Koponen (1 $9, \mathrm{FMNH})$.

Distribution. Palaearctic (Belgium, Bulgaria, France, Ireland, Israel, Italy, Kyrgyzstan, Netherlands, Russia, Spain, Sweden, United Kingdom), Australasian (New Zealand), and Neotropical (Argentina, Chile) Regions (TRIAPITSYN 2015b). New species record for Finland.

\section{Anagrus (Anagrus) subfuscus Foerster, 1847}

Anagrus (Anagrus) subfuscus FoERster (1847: 214-215). Type locality (of the neotype designated by CHIAPPINI 1989: 109): Belgium, Flemish Brabant, Leuven, Egenhoven. NeOtYPE: $q$ [ISNB], examined (TRIAPITSYN 1998).
?Anagrus (Anagrus) ensifer DeBAuche (1948: 136-137). Type locality: Belgium, Flemish Brabant, Tervuren, Vossem. HoLotyPE: $q$ (ISNB), examined (TRIAPITSYN 1998).

Material examined. $\boldsymbol{N}$ : Nurmijärvi, Kaanaanmetsä (6704:3381), 1.vii.1992, M. Koponen (1 ð̋ 1 †, FMNH). Sa: Mikkeli, Hietala (6680:3381), 12.vii.1981, M. Koponen (1 q, FMNH). Ta: Janakkala, Kalpalinna (6757:8369), 7.vii.2017, V. Vikberg (1 q, VVCT).

Remarks. Some female specimens from Finland, more or less attributable to A. subfuscus, as defined by CHIAPPINI (1989) and Triapitsyn (2015b), have an mps on F3 of at least one of the antennae and the ovipositor length: protibia length ratio of 3.5-4.0, thus being intermediate between $A$. subfuscus and $A$. ensifer. That may be indicative to their potential conspecificity which, however, will need to be further demonstrated by a combination of detailed morphometric and molecular studies that are beyond the scope of this communication. According to TRIAPITSYN (2015b), females of the former have one mps on F3 and the ovipositor length: protibia length ratio of 3.0-3.4 whereas those of the latter nominal species lack an mps on F3 and have the ovipositor length: protibia length ratio of 3.9-4.0. However, presence or absence of mps on F3 of the female antenna may vary in several other species of Anagrus (TRIAPITSYN 2015b), such as $A$. incarnatus Haliday, 1833 (TriAPITSYN et al. 2018).

Distribution. Palaearctic (Belgium, Bulgaria, Denmark, France, Germany, Greece, Italy, Japan, Poland, Romania, Russia, Spain, Switzerland, United Kingdom), Nearctic (Canada, USA), and Neotropical (Argentina) regions (TRIAPITSYN 2015b). New species record for Finland.

\section{Anagrus (Paranagrus) optabilis (Perkins, 1905)}

Material examined. FINLAND: Ta: Janakkala, Leppälampi (6766:3379), 2.viii.2009, marshy lakeside, V. Vikberg (1 q, VVCT; determined by V. Vikberg in 2010 as A. panicicolae Sahad, 1984, a synonym of A. optabilis, as well as more females at the same site in the following years (most recently in 2016). CANARY ISLANDS: Tenerife Island, Puerto de la Cruz, Parque Taoro, 20.xii.1997, M. Koponen (2 우, FMNH). MADEIRA: Madeira Island: Monte, 550 m, 3.xi.1996, M. Koponen (1 q, FMNH); Vaie do Paraiso, 740 m, 6.xi.1996, M. Koponen (2 우, FMNH).

Distribution. Palaearctic (China, Japan, Republic of Korea, Russia, Spain), Afrotropical (Cape Verde, Madagascar, Mauritius, Réunion, South Africa, Yemen), Australasian (Australia, New Zealand, Papua New Guinea), Nearctic (USA), Oceanian (Fiji, Guam, Hawaiian Islands, Samoa), and Oriental (Bangladesh, China including Taiwan, India, Indonesia, Malaysia, Philippines, Sri Lanka, Thailand) Regions (TRIAPITSYN 2015b). New subgenus and species record for Finland. Discovery of this species is indicative to the recent climate warming in Finland, which is the northernmost point of its distribution. The new records of $A$. (Paranagrus) optabilis from the Canary Islands and Madeira were omitted by KOPONEN \& TRIAPITSYN (2016).

\section{Anaphes (Anaphes) crassipennis (Soyka, 1946)}

Material examined. $\boldsymbol{K} \boldsymbol{b}$ : Joensuu (Central Hospital area), V. Vikberg, 20.vii.1973, emerged from an egg group of a tenthredinine sawfly (Hymenoptera: Tenthredinidae), probably Tenthredo sp. or Rhogogaster sp., found in tissue more on the underside of Vicia sepium leaf (12 $9+$, VVCT). Ta: Janakkala, Turenki, Rotary park (6758:3372), V. Vikberg: 7.x.2011 (1 q, VVCT), 11.x.2011 (1 +, VVCT). 
Distribution. Palaearctic Region (Austria, Belgium, Finland, Germany, Netherlands, Norway, Romania, Sweden, United Kingdom) (Noyes 2019).

\section{Anaphes (Anaphes) regulus Walker, 1846}

Material examined. Ta: Janakkala, V. Vikberg: Olila (6757:8375), 28.x.2016 (2 우, VVCT); Turenki, Rotary park (6758:3372), 29.ix.2016 $(1$ q, VVCT)

Distribution. Palaearctic Region (Belgium, Czech Republic, Denmark, Finland, Germany, Iceland, Netherlands, Poland, United Kingdom) (NoYEs 2019; SAMKová et al. 2020).

\section{Anaphes (Anaphes) sp.}

Material examined. Lkor: Sodankylä, Muotkanmaja, 1989, V. Vikberg $(1$ o, VVCT)

Remarks. This specimen was reared from an egg of a sawfly from the Pontania dolichura species group (Hymenoptera: Tenthredinidae) on Salix glauca. Galls were collected on 6.vii.1989 (rearing number 17/1989 VV). One gall contained no larva of the host, and one female mymarid emerged from the egg. It was mounted in euparal by V. Vikberg and initially identified to the former A. fuscipennis species group of Anaphes by S. V. Triapitsyn in 2017. Unfortunately, the specimen has only one complete antenna which is somewhat shriveled, so it is impossible to count mps on the funicular segments with any confidence; thus, its positive identification is impossible. Otherwise, this specimen mostly resembles those specimens of A. (Anaphes) ovipositor (Soyka, 1946) which have $1 \mathrm{mps}$ on $\mathrm{F} 4$ of the female antenna. It is definitely not A. (Anaphes) crassipennis (Soyka, 1946).

\section{Anaphes (Anaphes) stygius Debauche, 1948}

Material examined. Ta: Janakkala, Kalpalinna, Turistirinne (6760:3369), 3.xi.2011, V. Vikberg (1 +, VVCT).

Distribution. Palaearctic Region (Belgium, Bulgaria, Greece) (Noyes 2019). New species record for Finland.

\section{Anaphes (Patasson) silesicus (Soyka, 1946)}

Material examined. Ta: Janakkala, Turenki, Rotary park (6758:3372), 11.viii.2017, V. Vikberg (1 ㅇ, VVCT)

Distribution. Palaearctic Region (Belgium, Finland, Germany, Netherlands, Poland, Romania, Russia) (HeLléN 1974; Noyes 2019).

\section{Camptoptera magna Soyka, 1946}

Material examined. N: Espoo, Pirttimäki (6686:3370), 29.viii.1981, M. Koponen (1 ふै, FMNH). Nurmijärvi, Murhamäki (6710:3381), spruce swamp forest spring complex, 1.ix.1993, M. Koponen (1 ㅇ, FMNH). Sa: Rantasalmi, Haapaniemi, 27.vi.1941, W. Hellén (1 ô FMNH).

Distribution. Palaearctic (Austria, Belgium, China, Czech Republic, Denmark, France, Germany, Greece, Italy, Netherlands, Norway, Russia, Sweden) and Nearctic (USA) Regions (TRIAPITSYN 2014b). New species record for Finland.

\section{Camptoptera papaveris Foerster, 1856}

Material examined. Ta: Janakkala, Turenki, Mäntyniemi (6756:8370), emerged 1-4.i.2007 from Picea abies cones sampled from a fallen dead tree (taken to indoor rearing 17.xii.2006; host unknown), V. Vikberg (8 ổ 26 우, VVCT).

Distribution. Palaearctic (Austria, Belgium, Bulgaria, China, Czech Republic, Denmark, Finland, France, Germany, Greece, Hungary, Italy, Japan, Kyrgyzstan, Netherlands, Poland, Portugal, Romania, Russia, Serbia, Slovakia, Spain, Switzerland, United Kingdom), Afroropical (South Africa), Nearctic (Mexico, USA), Neotropical (Argentina), and Oriental (India) Regions (TRIAPITSYN 2014b, ANWAR et al. 2020).

\section{Cleruchus megatrichus Novicky, 1965}

Material examined. FINLAND: $\boldsymbol{N}$ : Nurmijärvi, Simonsberg (6705:3378), 13-18.vii.1992, window trap in hollow maple, M. Koponen ( 2 우, FMNH). Ta: Janakkala, Turenki, Rotary park (6758:3372), 18.iv.2014, V. Vikberg (1 §̂, VVCT). Loppi, Räyskälä (6740:3343), airport,

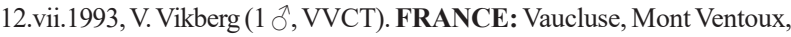
vii.1978, M. W. R. de Vere Graham (4 o,$+ \mathrm{BMNH})$.

Distribution. Palaearctic Region (Poland, Spain) (TRIAPITSYN 2014a). New species records for Finland and France.

\section{Cleruchus pluteus Enock, 1909}

Material examined. $\boldsymbol{A b}$ : Karjalohja (6685:3323), 19.vi.1992, M. Koponen (1 9 , FMNH). Lohja (6693:3334), 19.vi.1992, M. Koponen (1 §, FMNH). Parainen, Kuitia (6695:3245), 29.vi.2017, J. Paukkunen, pan trap (1 今े, UCRC ENT 00498737; molecular voucher D5924, J. M. Heraty Laboratory at University of California, Riverside, California, USA). $\boldsymbol{K} \boldsymbol{b}$ : Tohmajärvi (6909:3660), 21.vii.1982, M. Koponen (1 ڤ̂, FMNH). St: Vammala (6814:3286), 1.vii.1993, M. Koponen (1 \&, FMNH).

Distribution. Palaearctic Region (Belgium, Bulgaria, Canary Islands, Czech Republic, Denmark, Finland, Germany, Greece, Italy, Netherlands, Poland, Romania, United Kingdom) (TriaPITSYN 2014a; KoPONEN \& TriaPITSYN 2016).

\section{Cleruchus taktochno Triapitsyn, 2014}

Material examined. $N$ : Nurmijärvi (6704:3380), 28.v.1992, M. Koponen (1 Ĵ, FMNH). Ta: Janakkala, Kalpalinna (6757:8369), 7.vii.2017, V. Vikberg (1 ふૈ, VVCT). Loppi, Räyskälä (6740:3343), airport, 12.vii.1993, V. Vikberg (1 đ̊, VVCT). Pälkäne (6802:3351), 23.v.1982, M. Koponen (1 §, FMNH). Sa: Mikkeli [rural municipality], Kivilahdentie 6 (6839:3506), 1.vi.2001, M. Koponen (1 $\lesssim 1$ \&, FMNH).

Distribution. Palaearctic Region (Belgium, Denmark, Poland) (TriapitsYn 2014a). New species record for Finland.

\section{Cosmocomoidea oxypygus (Foerster, 1856)}

Material examined. $N$ : Helsinki: Kannelmäki (6682:3383), M. Koponen: 10.viii.1980 (1 q, FMNH); 30.viii.1980 (3 우, FMNH); 6.ix.1980 (1 q, FMNH); 20.vii.1981 (1 ㅇ, FMNH); (labeled as Helsingfors), Mellungsby, 20.viii.1962, W. Hellén (1 †, FMNH). Hyvinkää (6714:3372), 25.viii.1992, swept from forest grasses, M. Koponen ( 2 우, FMNH). Nurmijärvi, Nummimäki (6702:3378), 5.ix.1989, M. Koponen (1 q, FMNH). Sipoo, Bakunkärr (6688:3400), 30.viii.1983, M. Koponen (1 9, FMNH). Ta: Janakkala, V. Vikberg: Hangastenmäki (6755:3369), 16.viii.2013 (15 우, VVCT); Helvetinvuori (6751:8377), 9.ix.1978 (1 \&, VVCT); Kalpalinna, Turistirinne (6760:3369), 15.viii.2013 (16 9 + , VVCT), 17.viii.2013, swept from Populus tremula (23 9 ㅇ, VVCT). Kl: Parikkala, Laurila, forest, 25.vii.1945, W. Hellén (1 +, FMNH). Tb: Rautalampi (6948:3495), 19.vii.1983, M. Koponen (1 , FMNH). Sb: Suonenjoki, Tyyrinmäki (6943:3504), 15.vii.1983, M. Koponen (1 9 , FMNH). Om: Alajärvi (6995:3355), edge of forest road, 18.viii.1982, M. Koponen (1 \&, FMNH). 
Distribution. Palaearctic (Belgium, Bulgaria, Germany, Greece, Hungary, Iran, Italy, Netherlands, Romania, Russia, Spain, Turkey, United Kingdom) and Nearctic (USA) Regions (TriapITSYN 2013). New species record for Finland.

\section{Cosmocomoidea tremulae (Bakkendorf, 1934) (Figs 3-4)}

Material examined. $\boldsymbol{A} \boldsymbol{b}$ : Lohja (labeled as Lojo), Lylyinen, 20.viii.1947, W. Hellén (1 + , FMNH). $\boldsymbol{N}$ : Helsinki: Kannelmäki (6682:3383), M. Koponen: 15.vi.1981 (4 우, FMNH), 25.vi.1981 (1 ㅇ, FMNH); Viikki: 29.viii.1982, Z. Yang [Yang Zhongqi] (1 + , FMNH); (6680:3390), 23.viii.1984, M. Koponen (2 우, FMNH). Nurmijärvi (6704:3381), edge of old-growth forest, 9.vii.1991, M. Koponen (1 +, FMNH). Sipoo, Bakunkärr (6688:3400), 30.viii.1983, M. Koponen (1 , FMNH). Ta: Hämeenlinna (6765:3361), 22.viii.1981, M. Koponen (1 +, FMNH). Hartola, Pyhäntaka (6774:3436), grove on a slope, 17.viii.1980, M. Koponen (2 웅, FMNH). Janakkala, V. Vikberg: Hangastenmäki (6755:3369), 16.viii.2013 (25 오, VVCT); Kalpalinna, Turistirinne (6760:3369): 15.viii.2013 (9 우, VVCT), 17.viii.2013, swept from Populus tremula (9 오오, VVCT); Turenki, Rotary park (6758:3372): 23.viii.2016 (1 ô 1 ㅇ, VVCT). Sa: Kangasniemi (6875:3487), lake shore, 16.ix.1995, M Koponen (1 ㅇ, FMNH). Pertunmaa, Joutsenranta (6823:3474), 5.ix.1982, M. Koponen (1 9 , FMNH).

Remarks. A single male of $C$. tremulae from Finland is described and illustrated here (Figs 3-4). BAKKENDORF (1934) provided a drawing of an antenna of the male of this species from Denmark, without actually describing it. Body (length of dry-mounted specimen $0.85 \mathrm{~mm}$ ) dark brown to black, antenna brown, legs brown to dark brown except tarsi mostly light brown.
Distribution. Palaearctic Region (Austria, Denmark, Russia, United Kingdom) (TriaPITSYN 2013). New species record for Finland.

\section{Dicopus minutissimus Enock, 1909}

Material examined. $N$ : Nurmijärvi, M. Koponen: (6707:3382),

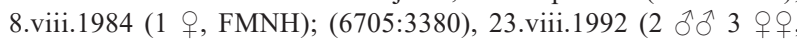
FMNH). Ok: Ristijärvi (7146:3565), 15.viii.1982, M. Koponen (1 ㅇ, FMNH)

Distribution. Palaearctic Region (Austria, Bulgaria, Czech Republic, Poland, Romania, Spain, Switzerland, United Kingdom) (BAquero \& Jordana 2002; Triapitsyn 2015a; NoYes 2019; SAMKová et al. 2020). New genus and species record for Finland.

\section{Dicopus moscovit Triapitsyn, 2015 (Figs 5-6)}

Material examined. $\boldsymbol{N}$ : Helsinki, Kannelmäki (6682:3383), 26.vii.1980, M. Koponen (1 \&, FMNH). Nurmijärvi, Murhamäki (6710:3381), spring forest, 1.ix.1993, M. Koponen (2 우, FMNH).

Remarks. Specimens from Finland, illustrated here to facilitate recognition of this minute species (Figs 5-6), match well its holotype and the original description (TRIAPITSYN 2015a). Body length of the dry-mounted, air-dried females is $0.23-0.30 \mathrm{~mm}$; the body (Fig. $5 \mathrm{~A}$ ) is dark brown except mesosoma is a little lighter (brown).

Distribution. Palaearctic Region (Russia) (TRIAPITSYN 2015a). New genus and species record for Finland.

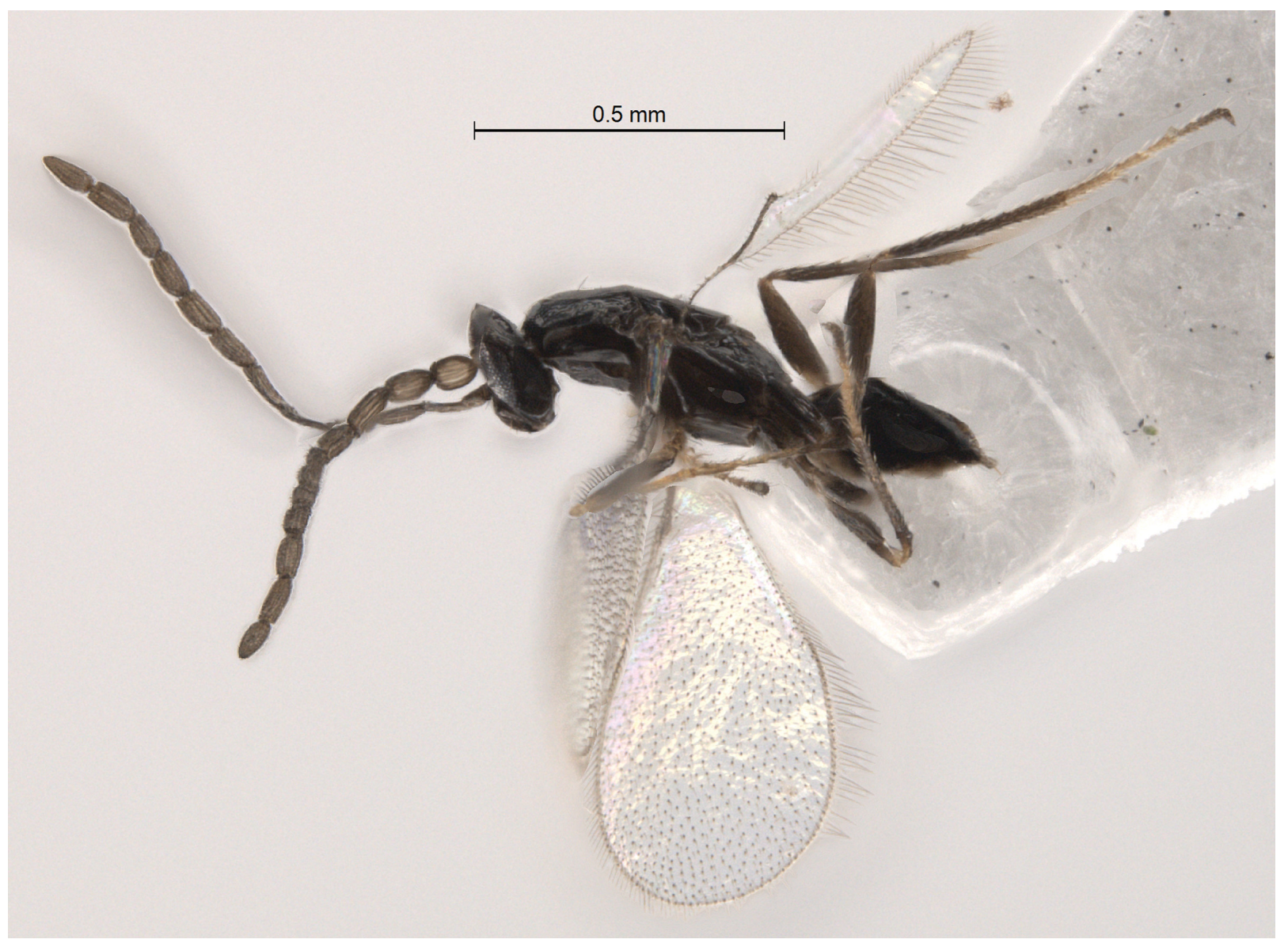

Fig. 3. Cosmocomoidea tremulae (Bakkendorf, 1934), male (Rotarypuisto, Turenki, Tavastia Proper, Finland), habitus in lateral view. 


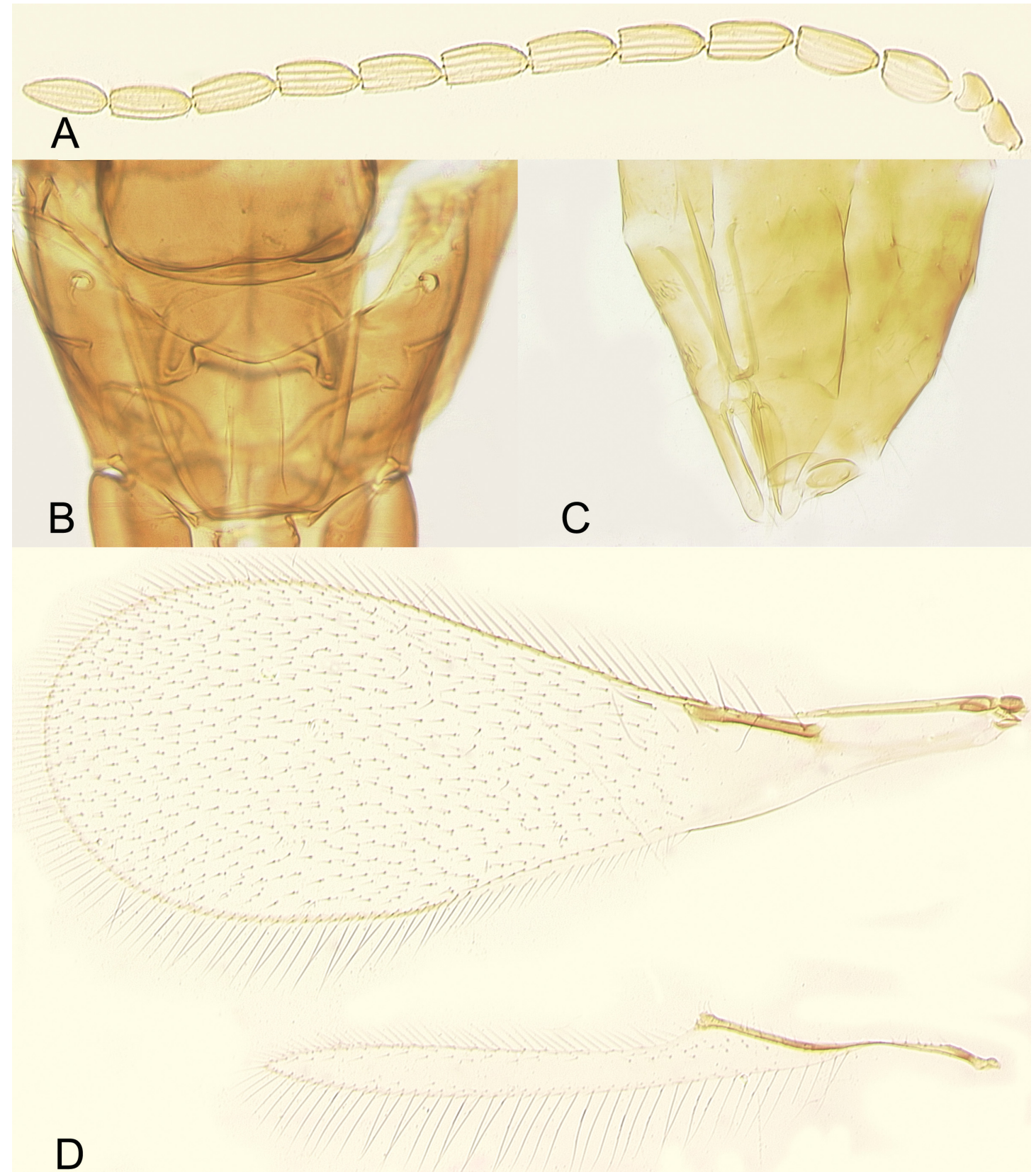

Fig. 4. Cosmocomoidea tremulae (Bakkendorf, 1934), male (Rotarypuisto, Turenki, Tavastia Proper, Finland): A - antenna; B - propodeum; C - genitalia; $\mathrm{D}-$ fore and hind wings.

\section{Erythmelus (Erythmelus) agilis (Enock, 1909)}

Material examined. Ta: Janakkala, Kalpalinna (6757:8369), 7.vii.2017, V. Vikberg $(1$ q, VVCT).

Distribution. Palaearctic (Belgium, Bulgaria, Czech Republic, Denmark, Finland, Germany, Greece, Italy, Kyrgyzstan, Netherlands, North Macedonia, Norway, Russia, Serbia, Sweden, Switzerland, United Kingdom) and Nearctic (Canada, USA) Regions (TRIAPITSYN 2003b; TriAPITSYN et al. 2007; SAMKOvÁ et al. 2020).

\section{Eustochus Haliday, 1833}

Caraphractus Walker, 1846, syn. nov., downgraded to a subgenus of Eustochus.

Remarks. The diagnoses of Eustochus Haliday, 1833 by Huber \& Baquero (2007) and Pricop \& Moglan (2016) are accepted here and expanded as follows: clava of female antenna 1- (entire), 2- or 3-segmented. Caraphractus Walker, 1846 was considered to be most closely related to Eustochus of which the former might be a derived offshoot; their only more or less significant difference was the claval segmentation of the female antenna: entire in the former but 2- or 3-segmented in the latter genus (HUBER \& BAQUERO 2007). Both genera were known from eggs of Coleoptera (Triapitsyn 2012; Pricop \& Moglan 2016) and are strictly Holarctic in distribution (HUBER \& BAQUERO 2007). However, our discovery of two new species of Eustochus from Finland and Germany with an entire clava (see below) shows that the variable segmentation of the clava in Eustochus is not a good genus-defining character, hence the proposed synonymy of Caraphractus syn. nov. with the earlier described Eustochus; furthermore, the former is 


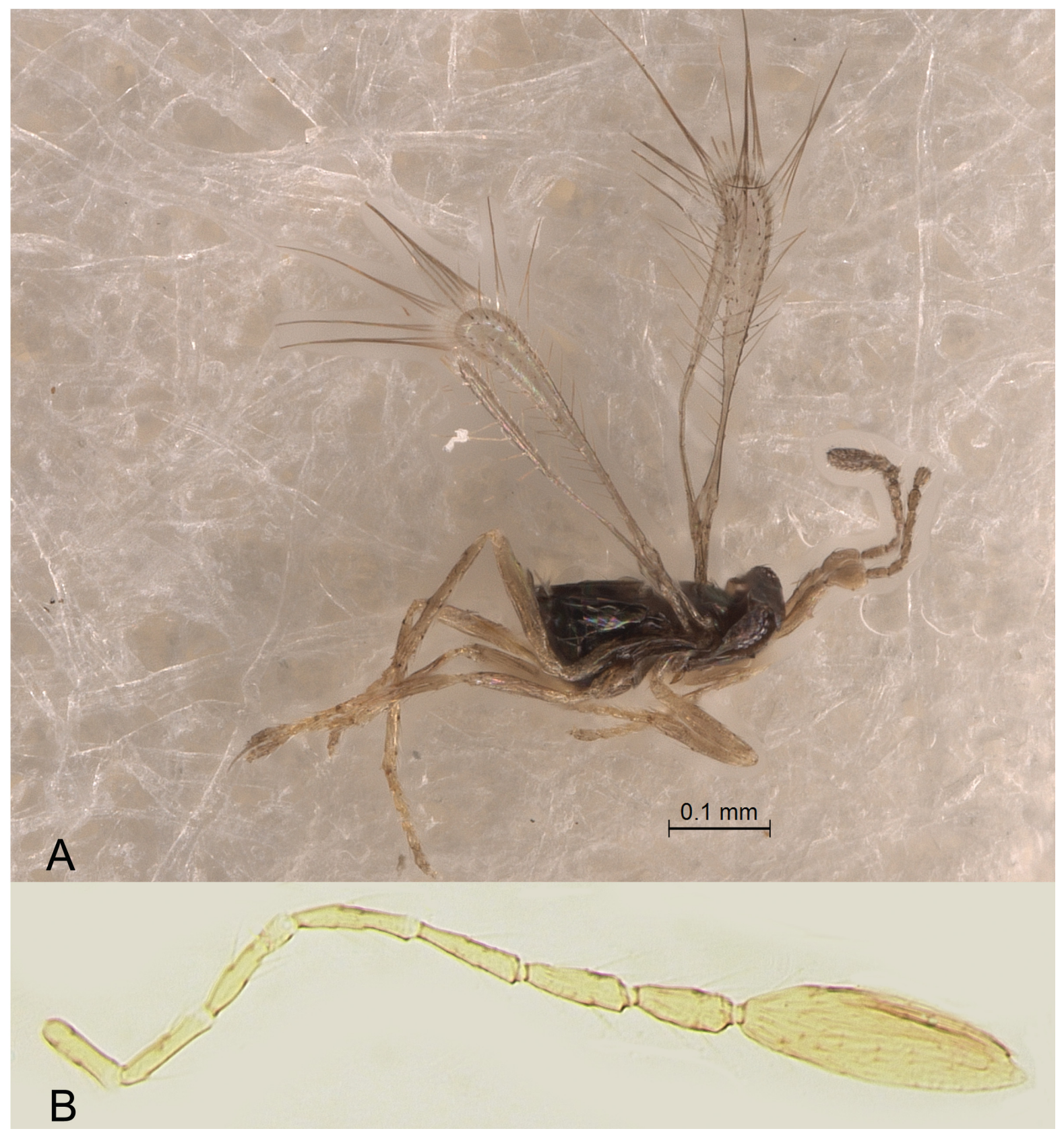

Fig. 5. Dicopus moscovit Triapitsyn, 2015, female: A - habitus in lateral view (Nurmijärvi, Uusimaa, Finland); B - flagellum of antenna (Helsinki, Uusimaa, Finland).

treated here as its subgenus, E. (Caraphractus) stat. revid. Caraphractus, with its sole valid member, the type species C. cinctus Walker, 1846 (=Eustochus (Caraphractus) cinctus (Walker, 1846), comb. nov.), is very likely essentially nothing more than just an aquatic species of Eustochus. However, while proposing this new generic synonymy, we also downgrade the taxonomic status of Caraphractus to that of a subgenus of Eustochus for the following reasons kindly provided by John T. Huber (personal communication): in female Caraphractus, mandible with 3 serrated teeth (2, not serrated teeth in most Eustochus s. str. except with 3 teeth in E. (Eustochus) koponeni); petiole ventrally with strong reticulations (smooth in most Eustochus s. str. except in E. (Eustochus) koponeni) and without a longitudinal suture (suture present at least partially in most Eustochus s. str. except in E. (Eustochus) koponeni); first gastral tergum laterally with about 10 longish setae (such setae absent in Eustochus s. str.); mps absent on funicle segments (present on several segments in Eustochus s. str.). Also, male Caraphractus have 1 less antennal flagellar segment than male Eustochus s. str., but these are known only for E. (Eustochus) atripennis (Curtis, 1832).

\section{Eustochus (Caraphractus) cinctus (Walker, 1846), comb. nov.}

\section{(Fig. 7)}

= Caraphractus flavicollis Hellén, 1974 (junior subjective synonym, see TRIAPITSYN 2012).

Type material examined. Caraphractus flavicollis: HоLотуре: 우 (FMNH) on card labeled: 1. [printed] "Lojo"; 2. [printed] "Hellén"; 3. [printed] "Fennia"; 4. "4455"; 5. [an illegible word, followed by "cinctus", and another illegible word on the other side, all in pencil]; 6 . 


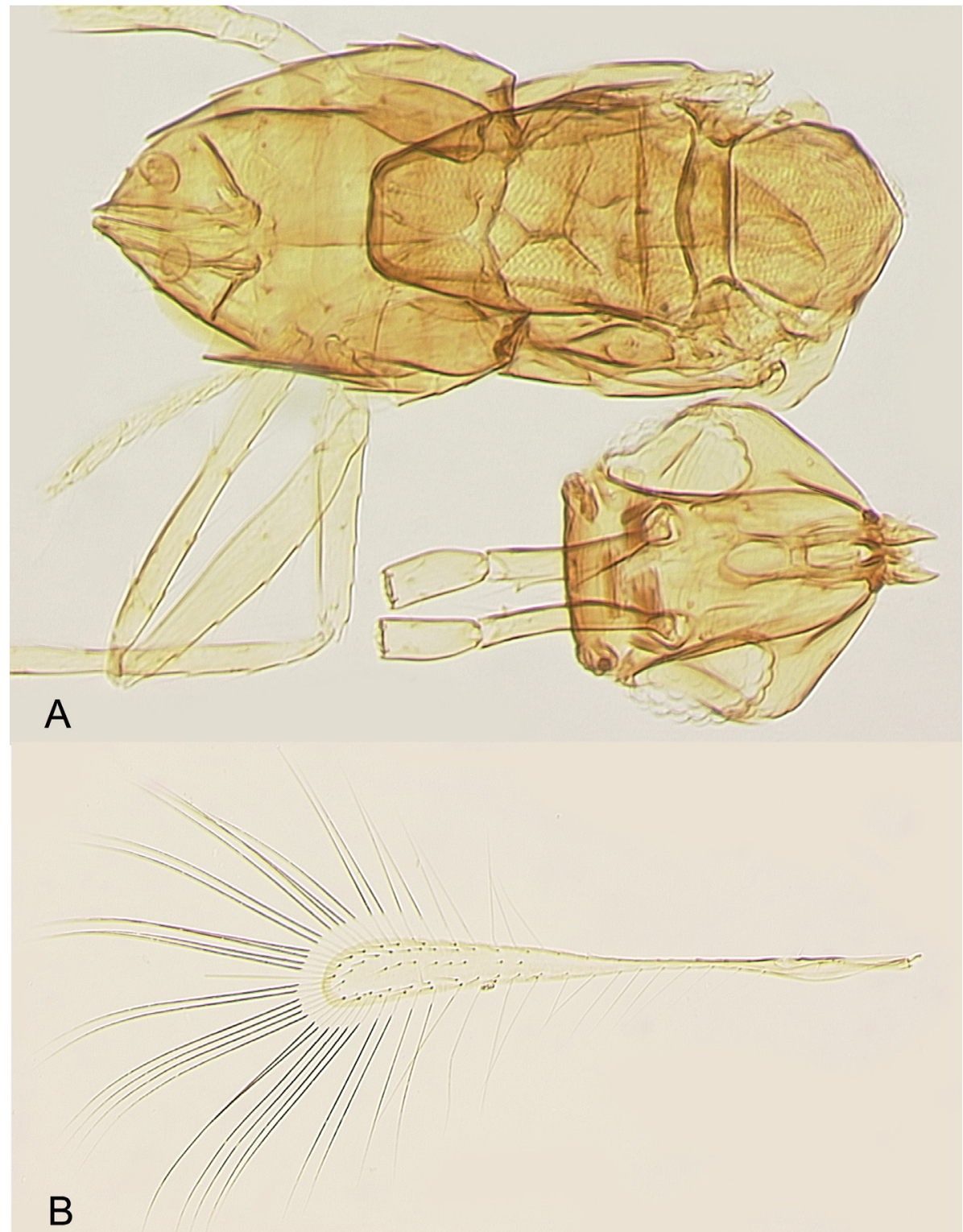

Fig. 6. Dicopus moscovit Triapitsyn, 2015, female (Helsinki, Uusimaa, Finland): A - mesosoma and metasoma, and head (with antennal scapes and pedicels attached); $\mathrm{B}$ - fore wing.

[red] "HOLOTYPE"; 7. [printed] "HOLOTYPE checked and labeled Thuróczy 2015"; 8. [barcode] "http://id.luomus.fi/GL.6281"; 9. [blue] "Photographed 2016 Pekka Malinen".

Additional material examined. Ta: Janakkala, Turenki, Rälssitie (6758:3373), 21.ix.2006, V. Vikberg (1 ㅇ, VVCT).

Remarks. The holotype female of Caraphractus flavicollis is complete and in good condition (Fig. 7); its body length is $1.03 \mathrm{~mm}$. Here we confirm its synonymy under $E$. ( $\mathrm{Ca}$ raphractus) cinctus, as it is within the normal range of its quite variable body color (TRIAPITSYN 2012).

According to the unpublished handwritten diary of $\mathrm{W}$. Hellén in FMNH, the exact type locality of the holotype of his Caraphractus flavicollis was Ab: Lohja (labeled as Lojo [in Swedish]) (Isokorvenlampi [= Isokorven pond]); the specimen with the original yellow-colored W. Hellén's number 4455 was collected on 12.viii.1949 by W. Hellén in the $10 \mathrm{~km}$ by $10 \mathrm{~km}$ grid cell 669:334 (according to the Finnish YKJ coordinate system), with the word "gungfly" [Swedish for 'floating mat'] following the pond name.
Distribution. Palaearctic (Austria, Belgium, Czech Republic, Denmark, Finland, Germany, Ireland, Russia, Sweden, Ukraine, United Kingdom) and Nearctic (Canada, USA) Regions (TriaPITSYN 2012; SAMKová et al. 2020).

\section{Eustochus (Eustochus) koponeni Triapitsyn, sp. nov. (Figs 8-9)}

Type material. HolotyPe: + (FMNH) on slide (Fig. 8B) labeled: 1. "SUOMI KP: Vimpeli 7008:349 10.7.1985 M. Koponen leg."; 2. "FMNH Mounted by V. V. Berezovskiy 2016 in Canada balsam"; 3. [magenta] "Eustochus koponeni Triapitsyn HOLOTYPE क"; 4. "Det. by S. V. Triapitsyn 2016". The type locality is in Southern Ostrobothnia ( Om) region of Finland; the specimen was captured by sweeping in an open bog Hallaneva. The holotype was remounted from a point (Fig. 8A).

PARATYPE: + (NMEG) on slide, labeled: "Germany, Sa-Anh, HZ, 4129/44 +4223/2 Blumentopfmoor N, Schierke, 640 m, Bodenfalle 1998-06-24 F. Burger". The locality is Blumentopfmoor (ca. 51 ${ }^{\circ} 47^{\prime} 55^{\prime \prime} \mathrm{N}$ $10^{\circ} 39^{\prime} 44^{\prime \prime}$ 'E, ca. $666 \mathrm{~m}$ ), a bog in Harz Mountains near the villages of Drei Annen Hohne and Schierke, Harz District, Saxony-Anhalt; the specimen was collected in a pitfall trap. 


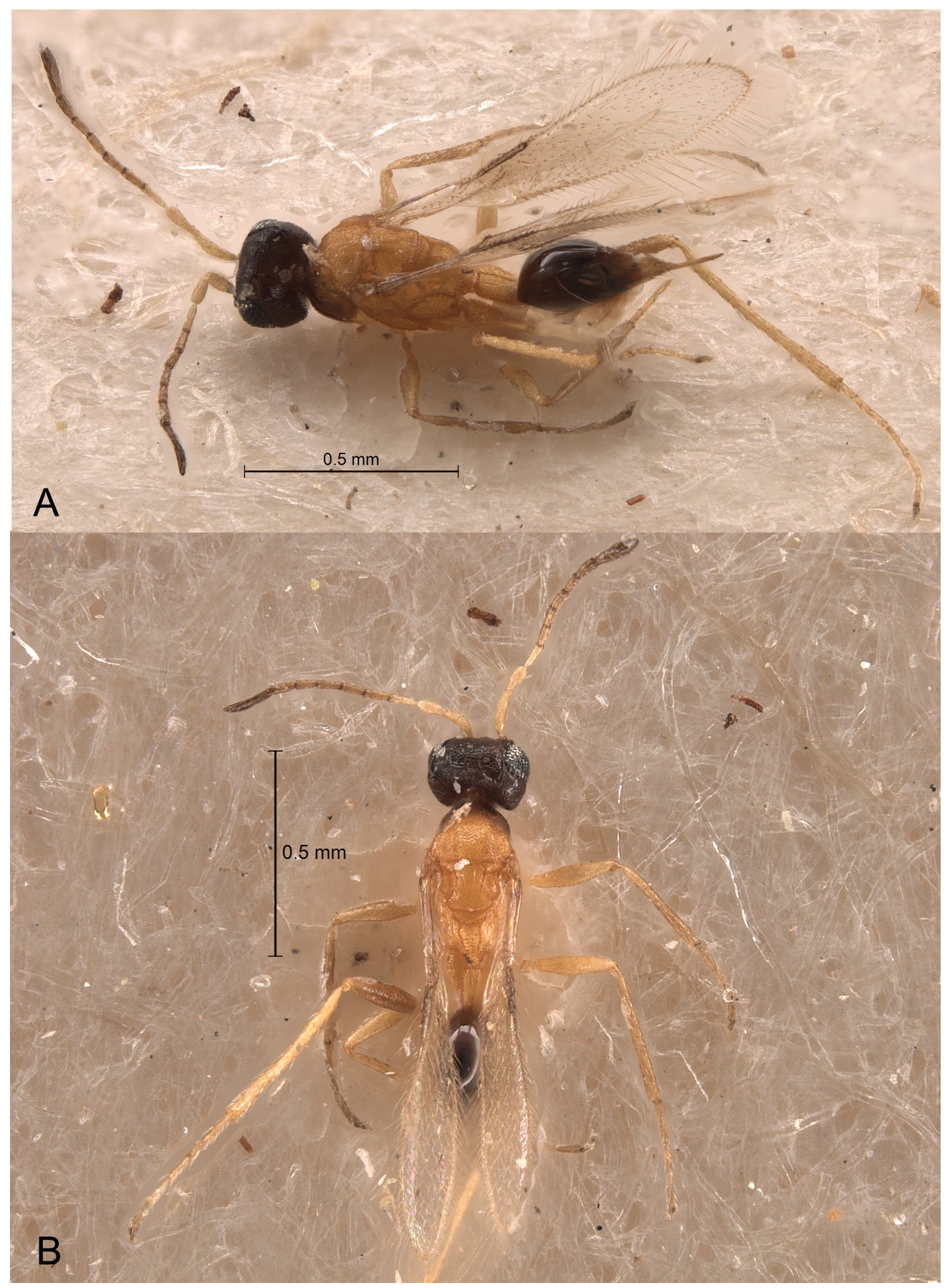

Fig. 7. Eustochus (Caraphractus) cinctus (Walker, 1846), female (holotype of Caraphractus flavicollis Hellén, 1974): A - habitus in dorsolateral view; $\mathrm{B}$ - habitus in dorsal view. 
Description. Female (holotype). Head black, rest of body (Fig. 8A) brown (mesosoma and petiole) to dark brown (gaster); appendages mostly brown to dark brown except 2 basal tarsomeres of hind leg light brown. Head (Fig. 8C) with reticulate sculpture; mandible 3-dentate. Antenna (Fig. 9A). Scape with a faint, inconspicuous sculpture, 4.6 times as long as wide (excluding a very short radicle); pedicel longer than any funicular segment; F2 and F3 the shortest and F4 the longest among funicular segments; mps on F4-F6 (apparently 2 on each); clava 2.3 times as long as wide, with 7 mps. Mesosoma (Fig. 9B) reticulate. Mesoscutum a little shorter than scutellum. Fore wing (Fig. 9E) almost 3.9 times as long as wide; venation extending to 0.46 of total wing length; longest marginal seta 0.74 times maximum width of wing; disc strongly infuscate (with brown) and densely setose. Hind wing (Fig. 9E) 16.5 times as long as wide; disc infuscate, longest marginal seta 3.6 times maximum width of wing. All coxae with reticulate sculpture, metafemur with a less conspicuous sculpture. Petiole (Figs 9C, D) reticulate, 1.5 times as long as wide, shorter than metacoxa. Ovipositor occupying 0.8 length of gaster (Fig. 9D), notably exserted beyond its apex (by 0.17 times own total length), 1.75 times length of mesotibia and 1.3 times length of metatibia.

Measurements of the holotype (mm). Body (of the air-dried [straight after being collected in a net], pointmounted specimen prior to slide-mounting): 0.860; head (of the air-dried, point-mounted specimen prior to slide -mounting): 0.132; mesosoma 0.330; mesoscutum: 0.090; scutellum: 0.103 ; petiole 0.070 ; gaster 0.478 ; ovipositor

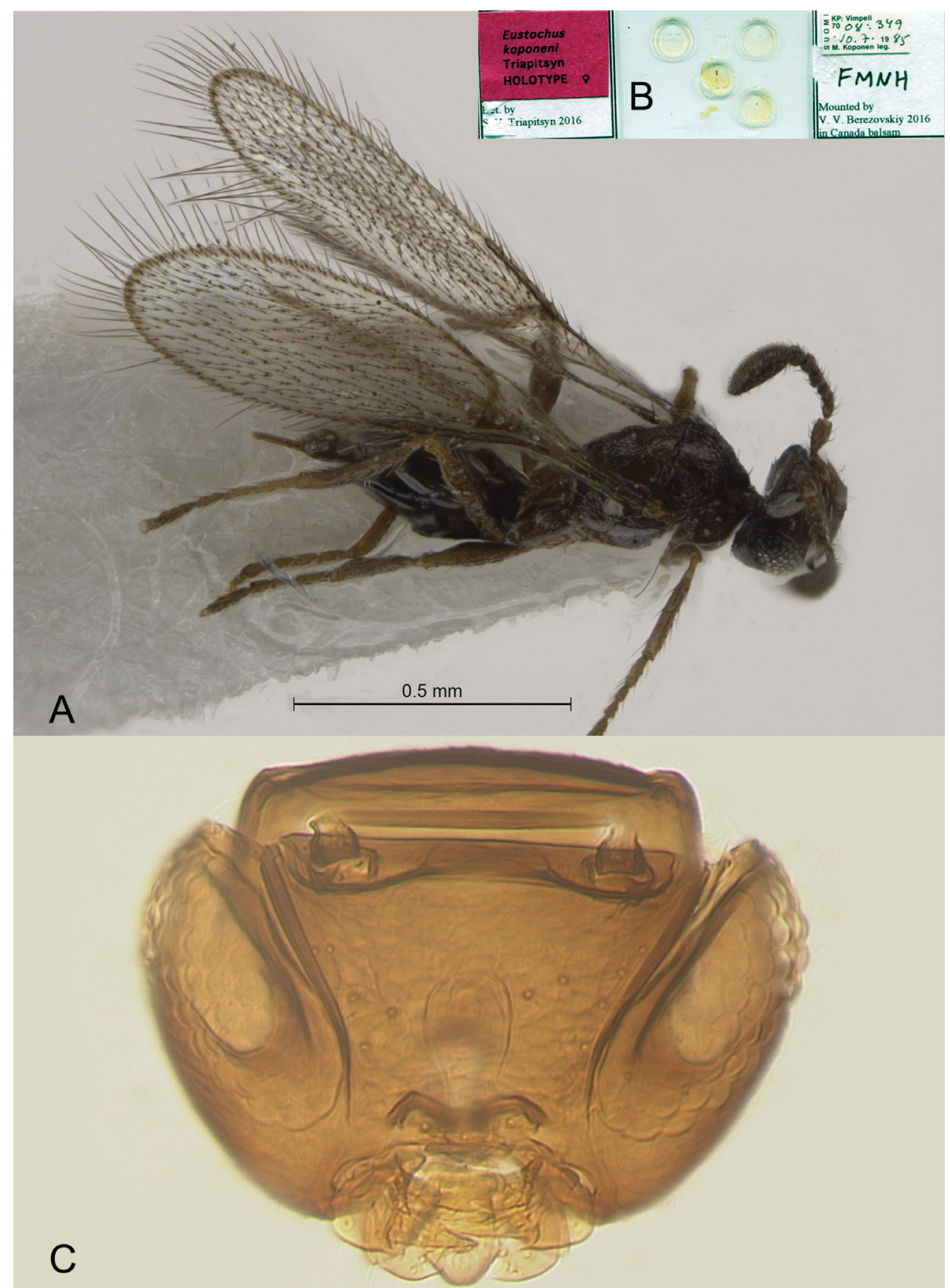

Fig. 8. Eustochus (Eustochus) koponeni Triapitsyn sp. nov., female (holotype): A - habitus in dorsolateral view (prior to slide-mounting); B - slide; $\mathrm{C}-$ head in frontal view. 
0.452 . Antenna: radicle 0.018 ; rest of scape 0.140 ; pedicel 0.060; F1 0.027; F2 0.024; F3 0.024; F4 0.040; F5 0.035; F6 0.036; clava 0.173 . Fore wing $0.935: 0.242$; venation 0.430 ; longest marginal seta 0.180 . Hind wing 0.695 : 0.042; longest marginal seta 0.151. Mesotibia: 0.258 ; metatibia: 0.351 .

Body length of the paratype (measured in ethanol) $1.073 \mathrm{~mm}$.

Male. Unknown.

Diagnosis. The new taxon, which belongs to the nominotypical subgenus of Eustochus as defined here, differs from all other described Eustochus species keyed in HUBER \&
BAQUERO (2007) in having an entire clava of the female antenna. Female of E. koponeni differs from that of Eustochus (Caraphractus) cinctus (Walker, 1846), comb. nov., which also has an entire clava, in having F1-F3 distinctly shorter than F4-F6, each of which also with mps (Fig. 9A); in the latter, funicle segments are subequal in length and all lack mps (TRIAPITSYN 2012: 22, fig. 1).

Eustochus (Eustochus) koponeni is most similar to apparently an undescribed species from Finland, known from a single female (Fig. 10A) in VVCT (Ta: Janakkala, Raimansuo (6760:3367), 27.vii.2017, V. Vikberg), which was also collected at a bog. Its clava is also entire, but

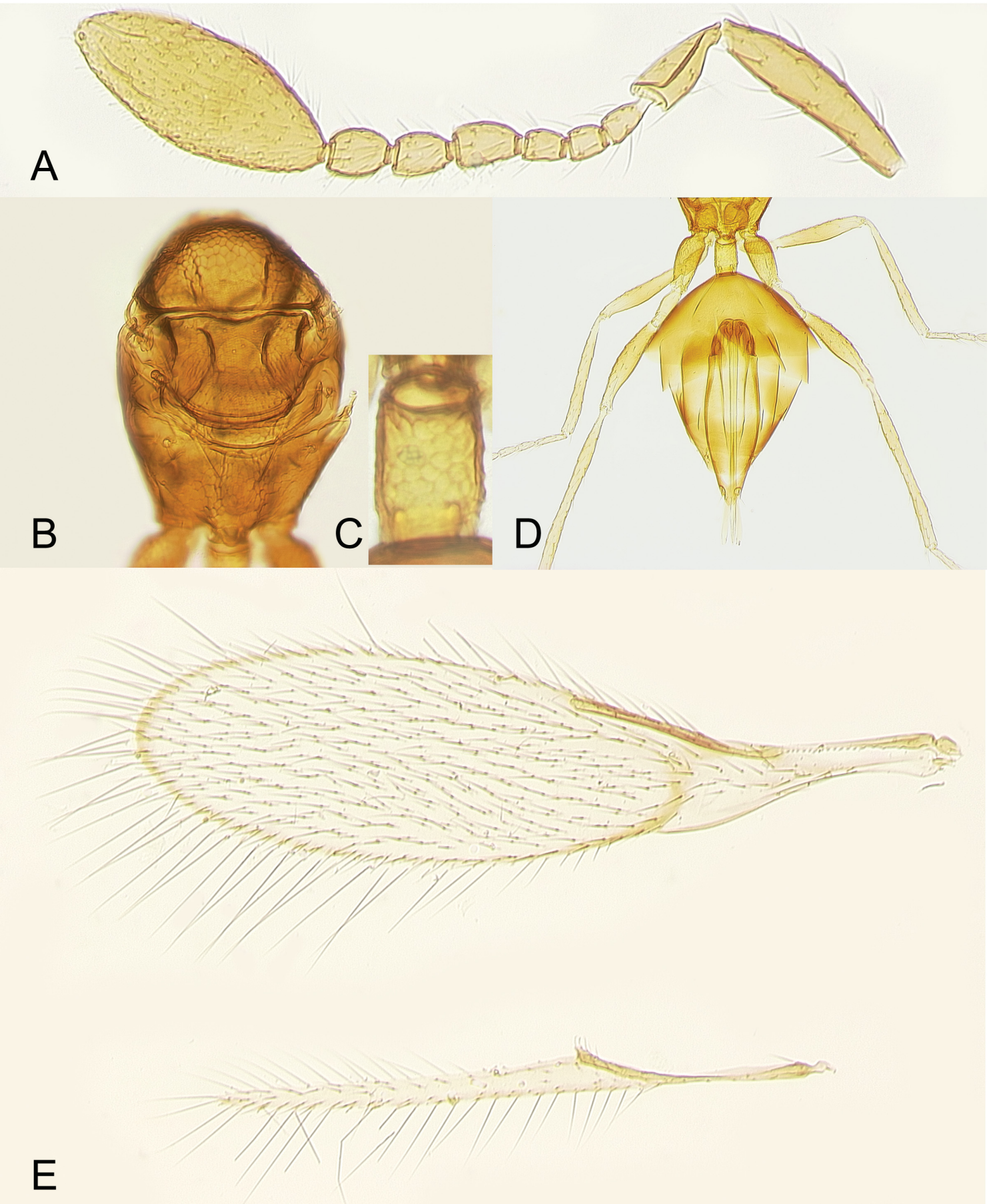

Fig. 9. Eustochus (Eustochus) koponeni Triapitsyn sp. nov., female (holotype): A - antenna (radicle attached to the head in Fig. 5C); B - mesosoma; $\mathrm{C}$ - petiole; D - metasoma; E - fore and hind wings. 
this Eustochus (Eustochus) sp. differs from that of E. koponeni in the following combination of features: antenna (Fig. 11A) with scape (minus radicle) 3.2 times as long as wide; fore wing (Fig. 11E) 3.3 times as long as wide and its longest marginal seta 0.5 times maximum wing width, hind wing (Fig. 11E) 17.8 times as long as wide; petiole (Fig. 11B) 1.8 times as long as wide; ovipositor short, occupying a little more than 0.5 length of gaster, and just barely exserted beyond apex of gaster (Fig. 11D), 1.5 times length of mesotibia and 0.95 times length of metatibia. It is not described here as a new taxon because its single available specimen has just one antenna (Figs 10A, 11A), and also because we do not know the full range of variability of these features in E. (Eustochus) koponeni. Body and head lengths of this Eustochus (Eustochus) sp., measured prior to slide-mounting, were $1.156 \mathrm{~mm}$ and $0.165 \mathrm{~mm}$, respectively. Its body (Fig. 10A) and antenna are black, legs are dark brown to black except first 3 metatarsomeres
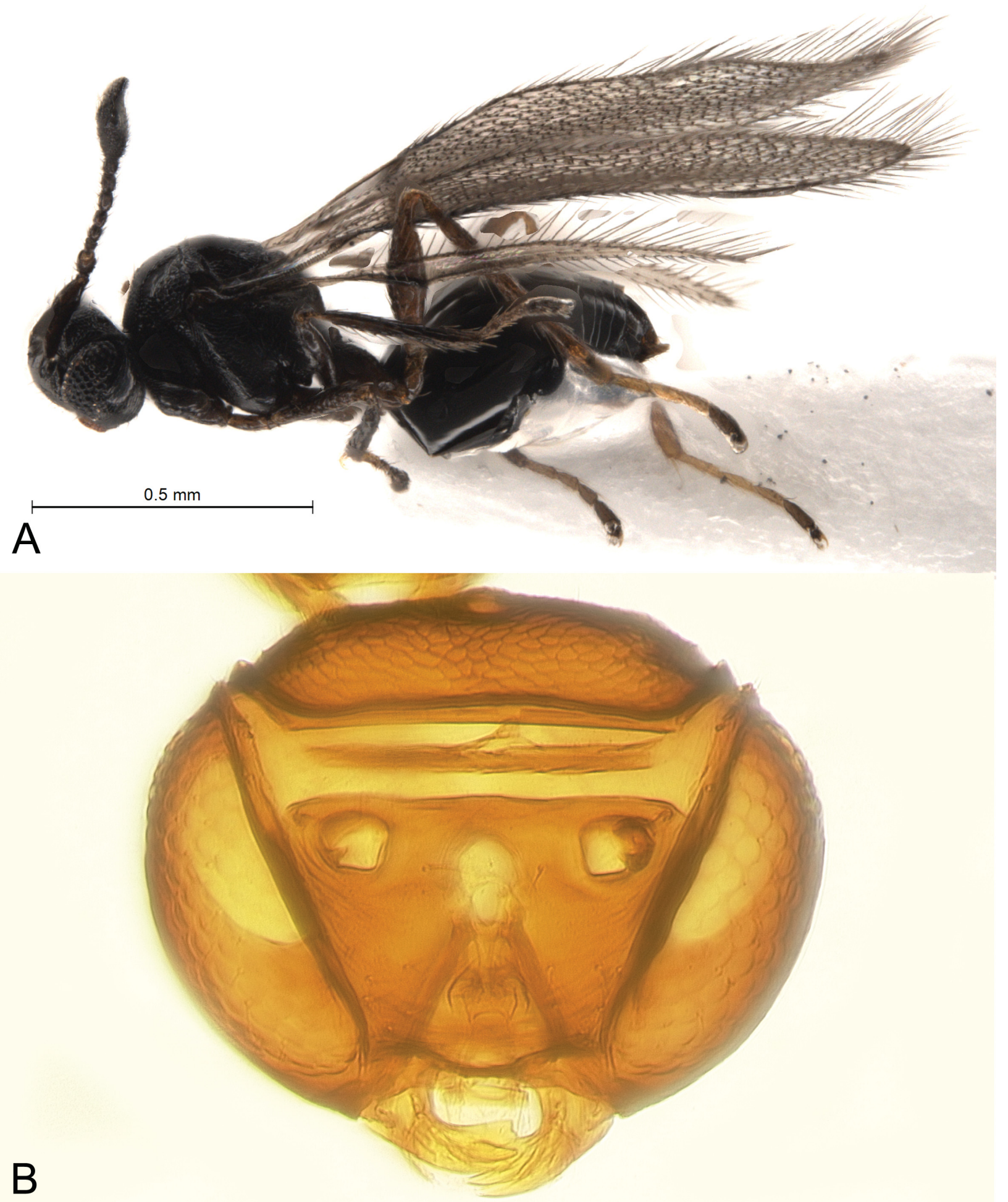

Fig. 10. Eustochus (Eustochus) sp. near koponeni, female (Raimansuo, Janakkala, Tavastia Proper, Finland): A - habitus (lateral view); B - head (frontal view). 
are light brown, and fore wing (Fig. 11E) disc is notably infuscate. The antenna (Fig. 11A) has mps on F4-F6 and clava. Also illustrated here, to facilitate its recognition, are its head (Fig. 10B) and mesosoma (Fig. 11C).

Etymology. The new species is named after its first collector (of the holotype).

Distribution. Palaearctic Region (Finland, Germany) (this paper).

\section{Gonatocerus aegyptiacus Soyka, 1950}

Material examined. Al: Saltvik (6709:3116), 28.vi.1983, M. Koponen (1 ô, FMNH). $\boldsymbol{N}$ : Helsinki, Viikki (6680:3390), 2.ix.1980, M. Koponen (1 ,
FMNH). Nurmijärvi, M. Koponen (6704:3381), forest edge, 24.vii.1992 (1

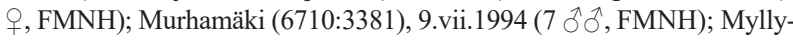
koski (6707:3382), 29.vii.1984 (3 우, FMNH). Ta: Janakkala, Kalpalinna, V. Vikberg: (6759:3370), 5.ix.2013 (1 , VVCT); Turistirinne (6759:3369): 6.ix.2013 (1 q, VVCT), 12.ix.2013 (1 §ै 1 q, VVCT). Sa: Mikkeli, M. Koponen: Hietalantie, 10.ix.2015 (2 우, FMNH); Otava (6835:3503), 18.vi.2008 (1 ふै, FMNH); Laajalampi, south shore, 20.ix.2015 (1 q, FMNH). Sb: Pieksämäki (6908:3502), hippodrome, 11.vii.2009, M. Koponen (1 †, FMNH). Kb: Liperi, Pärnävaara (6951:3630), 13.vi.2015, M. Koponen (2 $q$ ㅇ, FMNH).

Distribution. Palaearctic (Austria, Bulgaria, China, Denmark, Egypt, France, Greece, Hungary, Italy, Japan, Kyrgyzstan, Mongolia, Republic of Korea, Russia, Spain,
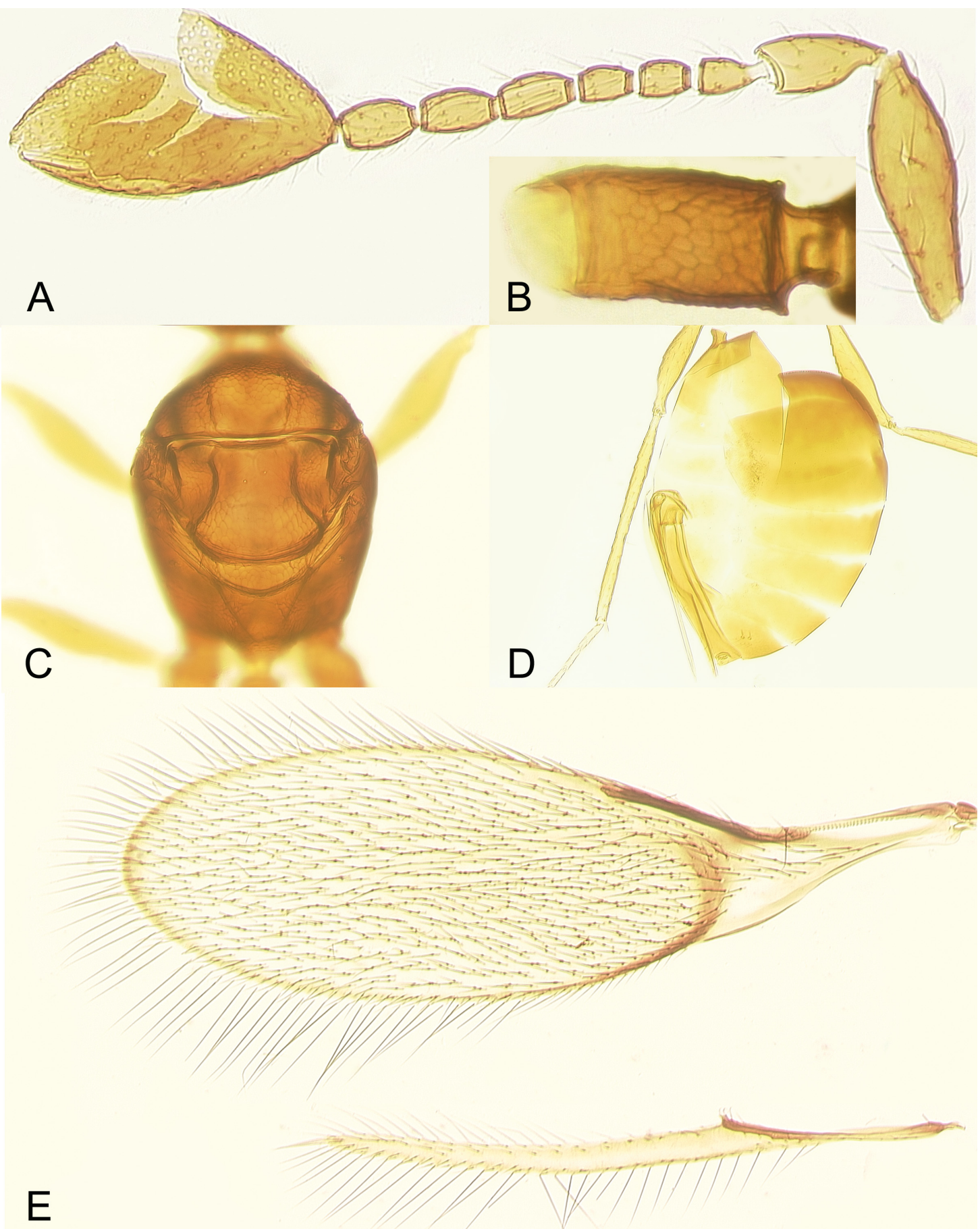

Fig. 11. Eustochus (Eustochus) sp. near koponeni, female (Raimansuo, Janakkala, Tavastia Proper, Finland): A - antenna; B - petiole; C - mesosoma; $\mathrm{D}$ - gaster (lateral view); E - fore and hind wings. 
United Kingdom), Afrotropical (South Africa, United Arab Emirates), Australasian (Australia), Nearctic (USA), Oceanian (American Samoa, Fiji, Northern Mariana Islands), and Oriental (India, Nepal, Pakistan, Taiwan, Thailand) Regions (TriapitsYn 2013, 2018). New species record for Finland.

\section{Gonatocerus fuscicornis (Walker, 1846)}

Material examined. Ta: Janakkala, V. Vikberg: Harviala (6763:3369), moist Betula wood, 15.ix.1978 (1 ㅇ, VVCT), 19.ix.1978 (2 우, VVCT), 22.ix.1978 (2 우, VVCT), 26.ix.1978 (1 ㅇ, VVCT); Kalpalinna: (6760:3370), 18.vi.1978 (1 ふै, VVCT); (6757:8369), 7.vii.2017 (1 q, VVCT); Turenki, Kuumola (6758:3372), 28.ix.1978 (1 , VVCT). $\boldsymbol{A b}$ : Karkkila, Mäensyrjä (6713:3346), reared from Deschampsia cespitosa, collected 5.v.1977, emerged v.1977, V. Vikberg (13 우, VVCT). $N$ : Vantaa, Hämeenkylä (6684:8378), 25.vi.1978, V. Vikberg (2 ㅇ, VVCT).

Distribution. Palaearctic (Armenia, Austria, Belgium, Bulgaria, Canary Islands, China, Czech Republic, Denmark, Finland, France, Georgia, Germany, Greece, Hungary, Ireland, Italy, Kyrgyzstan, Netherlands, North Macedonia, Norway, Poland, Republic of Korea, Romania, Russia, Spain, Sweden, Turkey, United Kingdom), Afrotropical (United Arab Emirates), Nearctic (USA), and Oriental (India, Taiwan) Regions (Triapitsyn 2013, 2018; KoPONEN \& TRIAPITSYN 2016; SAMKOvá et al. 2020).

\section{Lymaenon aureus (Girault, 1911)}

Material examined. $N$ : Nurmijärvi, M. Koponen: Hindrikanpolku (6708:3380): 28.vii.1987 (1 ㅇ, FMNH), 15.vii.1995 (1 ㅇ, FMNH); Kiljava (6712:3373), dry meadows, 25.vii.1992 (1 +, FMNH); Murhamäki (6710:3381), 9.vii.1994 (1 +, FMNH); Ruostesuo (6712:3381), 9.viii.1992 (1 ㅇ, FMNH). Sipoo, Bakunkärr (6688:3400), 24.vii.1983, M. Koponen (1 ㅇ, FMNH). Ta: Jämsä, Koukkulampi (6867:3409), 29.viii.1991, M. Koponen (2 우, FMNH). Sa: Mikkeli [rural municipality], Majalahdentie (6840:3506), 2.viii.1996, M. Koponen (1 ㅇ, FMNH). Mikkeli, Tusku (6843:3512), 10.viii.2009, M. Koponen (2 우, FMNH). Rautjärvi (6819:3615), 3.vii.1990, M. Koponen (1 ㅇ, FMNH). Tb: Rautalampi (East of Maukanvuori, 6945:3490), 19.vii.1983, M. Koponen (1 $9, \mathrm{FMNH})$.

Distribution. Palaearctic (Austria, Belgium, Bulgaria, China, Czech Republic, France, Georgia, Germany, Greece, Hungary, Italy, Japan, Kyrgyzstan, Morocco, Poland, Republic of Korea, Romania, Russia, Serbia, Slovakia, Spain, Sweden, Turkey, United Kingdom), Afrotropical (Republic of the Congo, South Africa, United Arab Emirates), Australasian (New Zealand), Nearctic (Bermuda, Canada, USA), Neotropical (Argentina, Brazil, Chile), and Oriental (China including Taiwan, India, Indonesia, Pakistan, Philippines) Regions (TriaPITSYN 2013, 2018; AISHAN et al. 2020). New species record for Finland (because $L$. gracilentus (Hellén, 1974) stat. restit. is not its synonym, see comments under L. gracilentus).

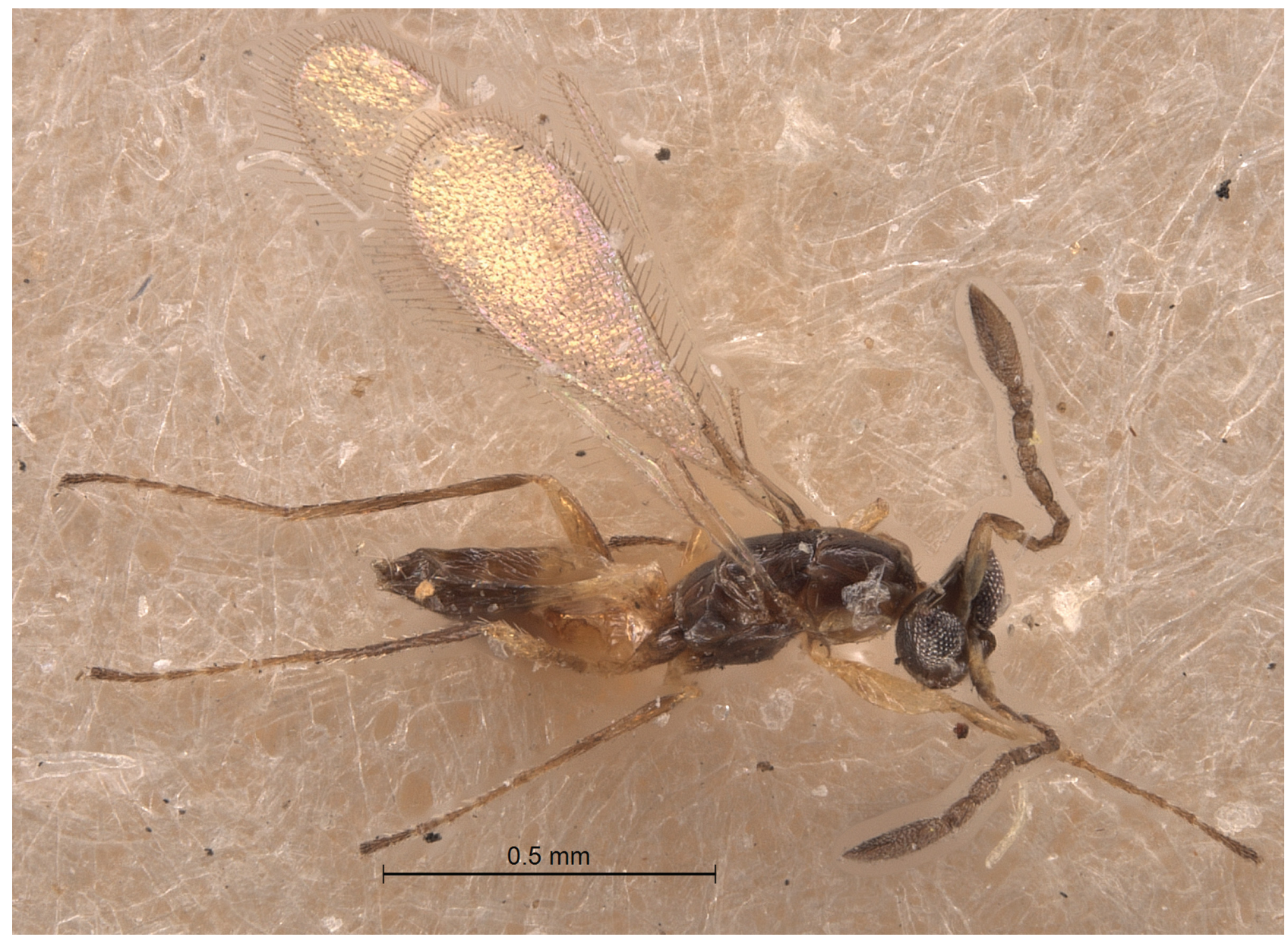

Fig. 12. Lymaenon gracilentus (Hellén, 1974), female (holotype of Gonatocerus gracilentus Hellén, 1974), habitus in dorsolateral view. 


\section{Lymaenon gracilentus (Hellén, 1974), stat. restit.}

(Figs 12-13)

Gonatocerus gracilentus Hellén, 1974: 11. Type locality: Finland, South Karelia, Parikkala, Tiviä (see explanation below). Resurrected as a valid taxon from the previous synonymy with Lymaenon aureus (Girault, 1911) by TrIAPITSYN (2013: 48, as Gonatocerus (Lymaenon) aureus Girault, 1911).

Lymaenon gracilentus (Hellén): HuBer (2015): 43 (listed as a synonym of Lymaenon aureus).

Type material examined. Gonatocerus gracilentus: НоLотуре: (FMNH) on card labeled: 1. [printed] "Parikkala Hellén"; 2. [very light yellow, faded] "4360" (Kl: Tiviä, 682:363, 16.vii.1940, Salix bushes on moist meadow); 3. [red] "HOLOTYPE"; 4. [in red ink, in W. Hellén's handwriting] "gracilentus Holotypus m. Hellén det."; 5. [printed] "HOLOTYPE checked and labeled Thuróczy 2015"; 8. [barcode] "http:// id.luomus.fi/GL.6282"; 9. [blue] "Photographed 2016 Pekka Malinen".

PARATYPES (presumed: specimens on which Hellén (1974) based the description of Gonatocerus gracilentus and included in his list of localities but not mentioned nor labeled as such): 2 우 on cards (FMNH), labeled: 1. "Bromarf", 2. "Hellén"; 1 on card (FMNH), labeled: 1. "Parikkala Hellén”, 2. [white] "6802", Kl: Laurila, 683:363, Carex bog; 1 on card (FMNH), labeled: 1. "Ekenäs", 2. "Hellén", 2. [white] "3" [this specimen belongs to Lymaenon Walker, 1846 but not necessarily to L. gracilentus];
1 on card (FMNH), labeled: 1. "Ekenäs", 2. "Hellén”, 2. [white] "432 13.8.1925" [this specimen belongs to Lymaenon but not necessarily to $L$. gracilentus]; 1 on card (FMNH), labeled: 1. "Joutseno", 2. "Hellén", 2. [white] "4916" (Honkalahti 678:358, sandy slope) [this specimen belongs to Gonatocerus Nees ab Esenbeck, 1834].

Additional material examined. $N$ : Nurmijärvi, M. Koponen: (6706:3381), 30.vii.1982 (1 q, FMNH); (6710:3381), 23.viii.1995 (1 ㅇ, FMNH); Kiljava (6712:3373), dry meadows, 25.vii.1992 (1 +, FMNH). Pyhtää, Ahvenkoski (66709:3470), 14.viii.1981, M. Koponen (1 9,FMNH). Sipoo (6688:3400), M. Koponen: 26.vii.1981 (1 \&, FMNH), 30.viii.1983 (1 q, FMNH). Vantaa, Tikkurila (6688:3392), 6.viii.1980, M. Koponen (1 9 , FMNH). St: Kokemäki, Kauvatsa (6804:3262), 10.viii.1992, M. Koponen (1 , FMNH). Nakkila (6818:3230), 10.viii.1992, M. Koponen (1 ㅇ, FMNH). Sa: Mikkeli: Otava (6837:3503), 30.vii.1990, M. Koponen (1 9 , FMNH); Soikkala (6830:3501), 6.viii.1993, M. Koponen (1 ㅇ, FMNH). Tb: Rautalampi, M. Koponen: Kalajanvuori, 17.vii.1983, M. Koponen (1 9, FMNH); Kerkonkoski, 18.vii.1983 (1 q, FMNH); East of Maukavuori (6945:3490), dry meadow, 19.vii.1983 (2 +o, FMNH). Vesanto, Niinivesi (6987:3473), 18.vii.1983, M. Koponen (1 9, FMNH). Sb: Kuopio (6957:3565), 18.viii.1983, M. Koponen (1 †, FMNH). Om: Lappajärvi, Nykälänniemi (7020:3331), 31.vii.1995, M. Koponen (2 오, FMNH).

Redescription. Female. Holotype (Fig. 12): body length $0.95 \mathrm{~mm}$; body mostly brown to dark brown except base

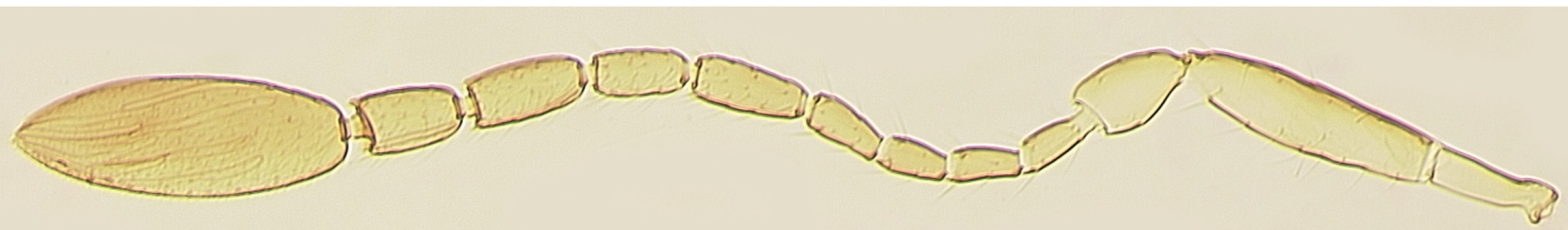

A

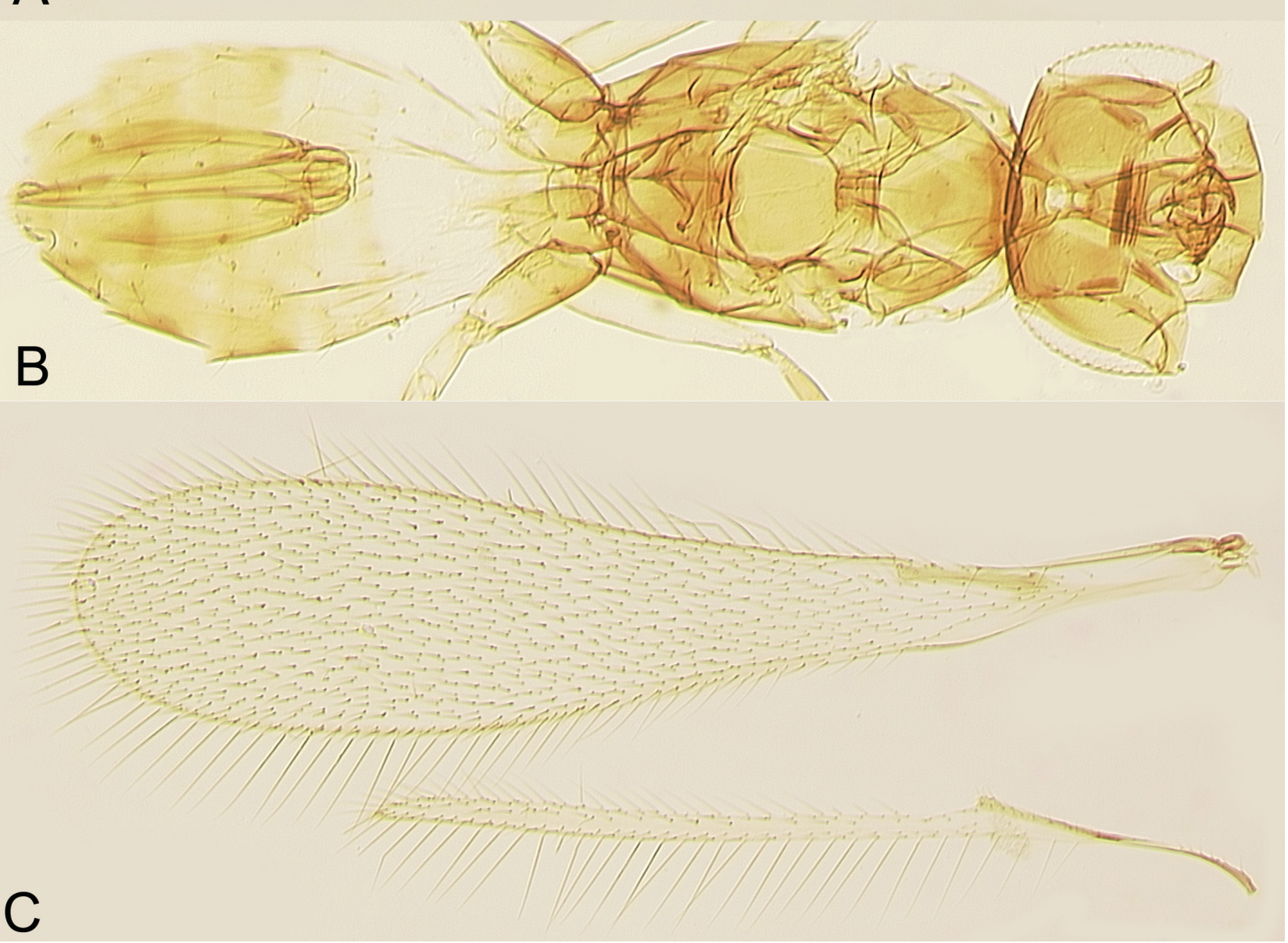

Fig. 13. Lymaenon gracilentus (Hellén, 1974), female (Sipoo, Uusimaa, Finland): A - antenna; B - body; C - fore and hind wings. 
of gaster light brown; F5, F7 and F8 with mps, F6 without mps; fore wing about 4 times as long as wide, disc more or less uniformly setose between marginal vein and cubital row of setae; ovipositor not exserted.

Non-type specimens from Finland: Body length 0.73-0.93 mm (air-dried, point-mounted specimens). Antenna (Fig. 13A) with scape (minus radicle) 3.6-4.2 times as long as wide; pedicel longer than F1; F1-F4 more or less subequal in length, shorter than following funicular segments; F5 about as long as F7 (the longest funicular segment), F8 a little shorter and F6 slightly shorter than F8; mps on F5 (1 or 2), F7 (1 or 2), and F8 (2); clava with $10 \mathrm{mps}$ ( 4 in the middle and 6 subapical), 2.7-3.2 times as long as wide, a little longer than combined length of F6-F8 but sometimes about as long as it. Fore wing (Fig. 13C) 4.1-4.7 times as long as wide; longest marginal seta $0.38-0.47$ times maximum wing width; disc almost hyaline, more or less uniformly setose behind marginal vein and densely setose elsewhere. Hind wing (Fig. 13C) 28-29 times as long as wide. Metasoma (Fig. 13B) with petiole about as wide as long. Ovipositor occupying about 0.6 length of gaster, not exserted beyond its apex, about 0.9 times length of mesotibia.

Male. Known and described from Finland (HELLÉN 1974) but not necessarily conspecific with Lymaenon gracilentus (like the presumed paratype from Joutseno); additional specimens are likely to be among the material from the country recently identified by S. V. Triapitsyn as Lymaenon spp.

Remarks. The holotype of this species (Fig. 12) is in fair condition (head and antennae are shriveled because the specimen was air-dried) and complete. According to the unpublished handwritten diary of W. Hellén in FMNH, the exact type locality of the holotype of his Gonatocerus gracilentus was $K l$ : Parikkala (Tiviä, 682:363 [10 km by 10 $\mathrm{km}$ grid number according to the Finnish YKJ coordinate system]); the specimen with the original yellow-colored W. Hellén's number 4360 was collected on 16.vii.1940 by W. Hellén on willow bushes in a moist meadow.

The holotype female of Gonatocerus gracilentus, invalidly designated as a lectotype by MaTTHEWs (1986: 227) because HelléN (1974: 11) specifically listed the specimen from Parikkala as a holotype, although without providing any other details (TRIAPITSYN 2013). Its synonymy under Gonatocerus chrysis (Debauche, 1948), which is a synonym of Lymaenon aureus (Girault, 1911) (Triapitsyn 2013; Huber 2015), by Matthews (1986: 227) was not justified because its examination revealed that it rather fits in the broad diagnosis of Lymaenon litoralis (Haliday, 1833), as given by TRIAPITSYN (2013) for Gonatocerus (Lymaenon) litoralis (Haliday, 1833). In the key to the Palaearctic species of Lymaenon Walker, 1846 (as Gonatocerus (Lymaenon)) by TRIAPITSYN (2013), the holotype of Lymaenon gracilentus and female specimens

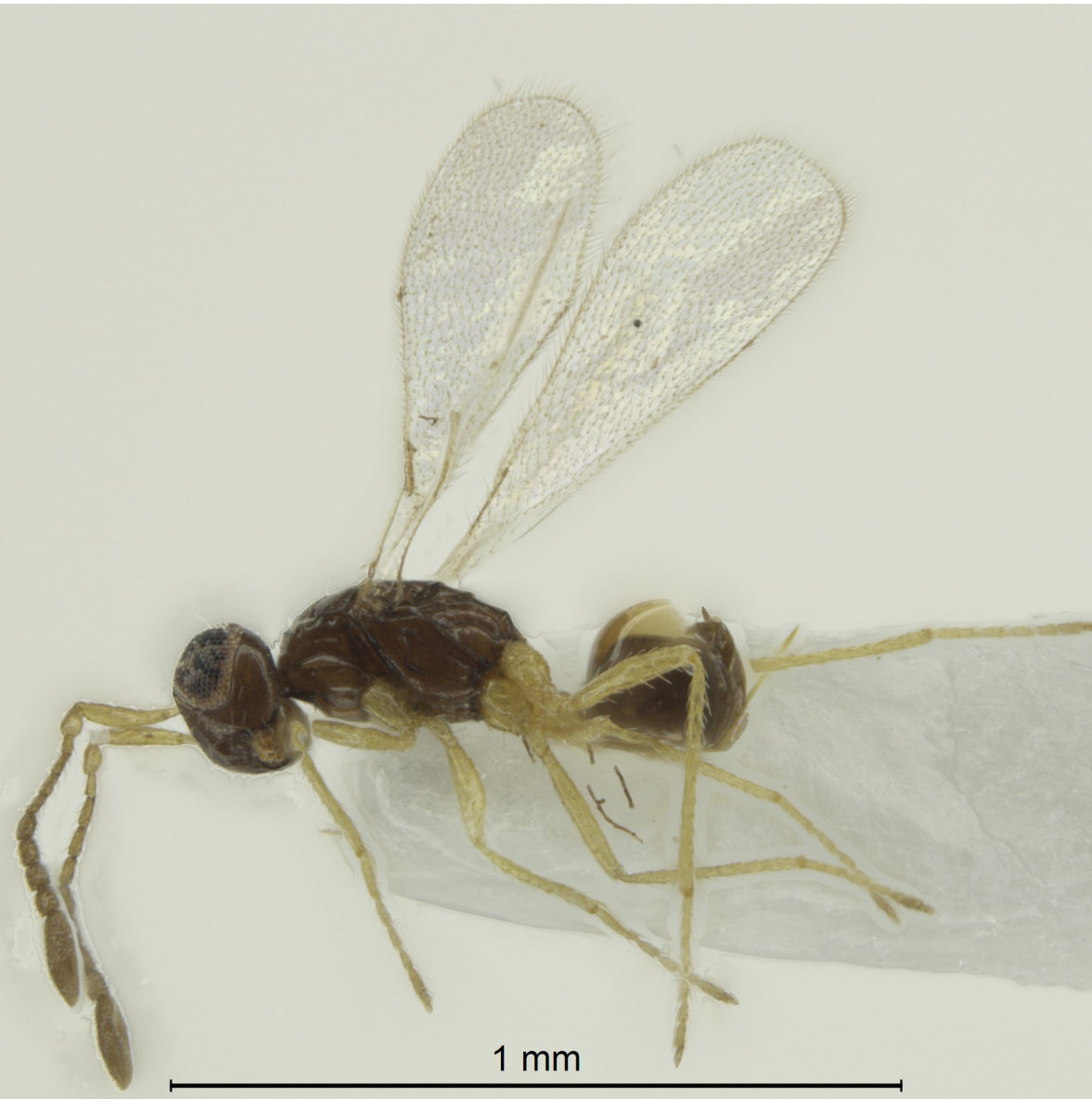

Fig. 14. Ooctonus sublaevis Foerster, 1847, female (Kistuskaidi, $69.940^{\circ} \mathrm{N} 26.565^{\circ} \mathrm{E}, 391 \mathrm{~m}$, Utsjoki Municipality, Lapland, Finland), habitus in lateral view. 
from Europe similar to it would end up in the second part of Couplet 18 (p. 40) as those Lymaenon litoralis which have the fore wing quite narrow, at least 3.9 times as long as wide. Because Lymaenon gracilentus is an already described species and at least for now can be separated from the typical $L$. litoralis using proportions of the female fore wing (at most 3.8 times as long as wide in the latter), we reluctantly resurrect the former as a valid taxon from its synonymy with $L$. aureus, with an understanding that in the future it could potentially be proven (for instance, using molecular methods) to rather be conspecific with L. litoralis.

Distribution. Palaearctic Region (Finland).

\section{Lymaenon longior (Soyka, 1946)}

Material examined. $\boldsymbol{N}$ : Nurmijärvi, M. Koponen: (6704:3381), edge of old forest, 24.vii.1992 (1 +, FMNH); Kiljava (6712:3373), dry meadows, 25.vii.1992, M. Koponen (1 +, FMNH); Raalantie (6710:3381), 27.vi.1995, gravel pit $(1 \stackrel{9}{ }, \mathrm{FMNH})$.

Distribution. Palaearctic Region (Austria, Belgium, Bulgaria, China, Denmark, France, Georgia, Germany, Greece, Hungary, Italy, Kyrgyzstan, Netherlands, Russia, Spain, Switzerland, Turkey, United Kingdom) (TrIAPITSYN 2013; Aishan et al. 2020). New species record for Finland.

\section{Ooctonus sublaevis Foerster, 1847 (Fig. 14)}

Material examined. $\boldsymbol{L} \boldsymbol{i}$ : Utsjoki Municipality, Kistuskaidi, $69.940^{\circ} \mathrm{N}$ 26.565 E E, $391 \mathrm{~m}, 1 . \mathrm{vi}-31 . v i i i .1991$, S. Schmidt, pitfall trap (5 우우 VVCT).

Remarks. This is one of the northernmost localities (almost $70^{\circ} \mathrm{N}$ ) in Finland (and also in the entire Europe) from where Mymaridae were ever collected (also captured there were several unidentified species of Anaphes, Polynema and the Gonatocerus group of genera).

Distribution. Palaearctic Region (Austria, Belgium, Bulgaria, China, Czech Republic, Finland, Germany, Japan, Norway, Poland, Russia, Sweden, Switzerland, Ukraine, United Kingdom) (Triapitsyn 2010; BaI et al. 2015; KOPONEN et al. 2019).

\section{Polynema (Doriclytus) atratum Haliday, 1833}

Material examined. Ta: Janakkala: Harviala (6763:3369), moist Betula wood, V. Vikberg: 15.ix.1978 (1 ㅇ, VVCT), 19.ix.1978 (5 오, VVCT), 25.ix.1978 (1 +, VVCT), 27.ix.1978 (1 \&, VVCT); Suurisuo, 6059’23”'N 2448'49'E, 137 m, 8.vii.2017, S. V. Triapitsyn \& V. Vikberg (4 우, UCRC); Viralanjärvi (6753:8367), 24.ix.1978, V. Vikberg (5 \&ᄋ, VVCT). Hämeenlinna, Katinen (6767:3364), 7.ix.1978, V. Vikberg (1 \&, VVCT). Ab: Karkkila, Mäensyrjä (6713:3346), reared from Alopecurus pratensis, collected 10.v.1977, emerged v.1977, V. Vikberg (1 q, VVCT).

Distribution. Palaearctic Region (Belgium, Denmark, Estonia, Finland, Greece, Iceland, Norway, Russia, United Kingdom) (Hellén 1974; NoYes 2019).

\section{Polynema (Doriclytus) euchariforme Haliday, 1833}

Material examined. $N$ : Vantaa, Hämeenkylä (6684:8378), 25.vi.1978, V. Vikberg (1 ㅇ, VVCT). Ta: Janakkala, V. Vikberg: Kalpalinna (6760:3370), 7.vii.1978 (1 q, VVCT); Koljala (6759:8371), 5.x.1978 (1 q, VVCT).
Distribution. Palaearctic Region (Austria, Belgium, Finland, Germany, Norway, Poland, Sweden, United Kingdom) (HelléN 1974; SCHUPPENHAUER \& TRIAPITSYN 2018; NOYEs 2019).

\section{Polynema (Polynema) flavipes Walker, 1846}

Material examined (1 ${ }^{\Uparrow} 42$ 우, FMNH). $\boldsymbol{A l}$ (Jomala), $\boldsymbol{A} \boldsymbol{b}$ (Dragsfjärd, Nauvo), $\boldsymbol{N}$ (Helsinki, Hyvinkää, Inkoo, Nurmijärvi, Porvoo [rural municipality]: Siuntio, Tammisaari), St (Nakkila), $\boldsymbol{T a}$ (Hartola), $\boldsymbol{S a}$ (Mikkeli [rural municipality]: Ristiina, Taipalsaari), $\boldsymbol{T} \boldsymbol{b}$ (Keuruu), $\boldsymbol{K} \boldsymbol{b}$ (Kitee), $\boldsymbol{O} \boldsymbol{m}$ (Alajärvi).

Distribution. Palaearctic Region (Czech Republic, Germany, Netherlands, Romania, Sweden, United Kingdom) (SCHUPPENHAUER \& TRIAPITSYN 2018; Noyes 2019; SAMKOVÁ et al. 2020). New species record for Finland.

\section{Polynema (Polynema) fumipenne Walker, 1846} (Fig. 15)

Material examined. Ta: Janakkala, V. Vikberg: Harviala (6763:3369), moist Betula wood, 15.ix.1978 (1 ㅇ, VVCT); shore of Räikälä River (6755:3369), 13.viii.1978 (1 ㅇ, VVCT).

Distribution. Palaearctic Region (Belgium, Denmark, Finland, Germany, Greece, Ireland, Romania, Russia, Serbia, Sweden, United Kingdom) (HeLléN 1974; Noyes 2019).

\section{Polynema (Polynema) fuscipes Haliday, 1833}

Material examined (14 $\widehat{\jmath} 71$ 우, FMNH). $\boldsymbol{A} \boldsymbol{b}$ (Halikko, Paimio), $\boldsymbol{N}$ (Hanko, Helsinki, Hyvinkää, Lapinjärvi, Kirkkonummi, Nurmijärvi, Sipoo), $\boldsymbol{K a}$ (Ylämaa), St (Nakkila, Rauma [rural municipality]), Ta (Forssa, Hartola, Janakkala, Lammi, Loppi), Sa (Mikkeli, Mikkeli [rural municipality], Ristiina), $\boldsymbol{O} \boldsymbol{a}$ (Ilmajoki), $\boldsymbol{T} \boldsymbol{b}$ (Hankasalmi), $\boldsymbol{S} \boldsymbol{b}$ (Maaninka).

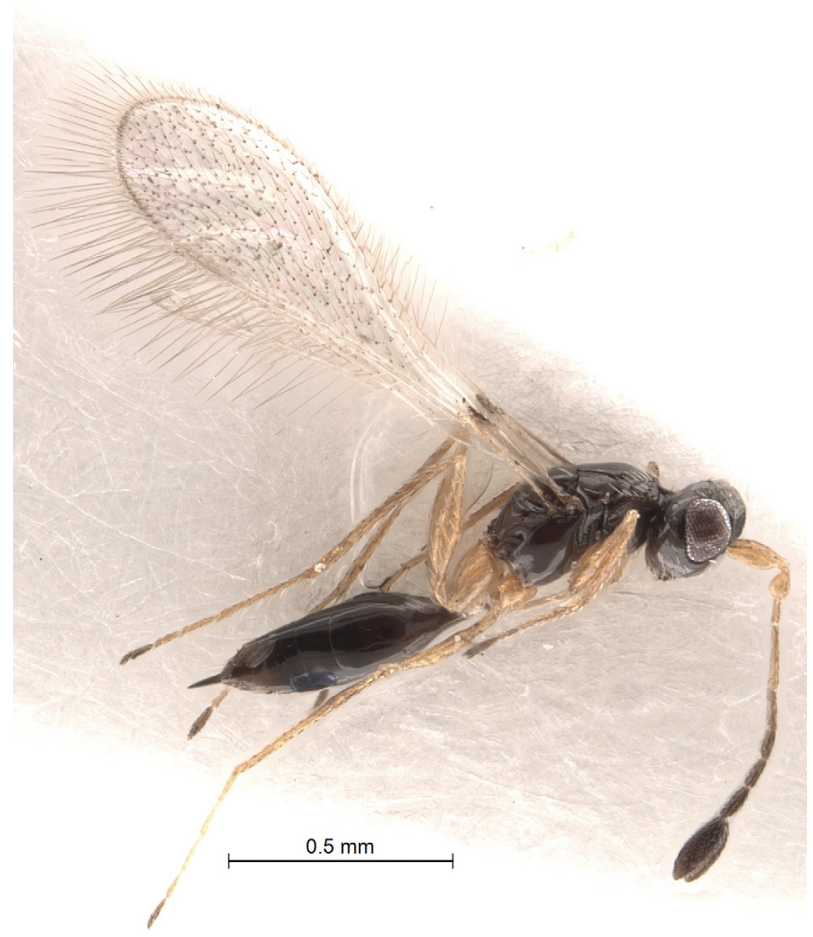

Fig. 15. Polynema fumipenne Walker, 1846, female (Pertunmaa, Southern Savonia, Finland), habitus in lateral view. 
Distribution. Palaearctic Region (Belgium, Bulgaria, Denmark, Germany, Greece, North Macedonia, Norway, Serbia, Slovakia, Sweden, Turkey, United Kingdom) (SCHUPPENHAUER \& TRIAPITSYN 2018; Noyes 2019). New species record for Finland.

\section{Polynema (Polynema) gracile (Nees ab Esenbeck, 1834)}

Material examined. Ta: Janakkala, Harviala (6763:3369), moist Betula wood, 19.ix.1978, V. Vikberg ( 2 우, VVCT).

Distribution. Palaearctic Region (Austria, Czech Republic, Denmark, Finland, Germany, Netherlands, North Macedonia, Serbia, Sweden, United Kingdom) (HeLléN 1974; SCHUPPENHAUER \& TRIAPITSYN 2018; Noyes 2019; SAMKová et al. 2020).

\section{Polynema (Polynema) pusilloides Debauche, 1948}

Material examined. Ta: Janakkala, Harviala, 15.ix.1978, V. Vikberg (1 q, VVCT).

Distribution. Palaearctic Region (Belgium) (NoyEs 2019). New species record for Finland.

\section{Polynema (Polynema) valkenburgense Soyka, 1931}

Material examined. N: Nurmijärvi, M. Koponen: Kiljava (6712:3373), dry meadows, 20.v.1993 (8 우, FMNH); Raalantie, Ahola (6710:3381), gravel pits, 23.vi.1996 (1 + , FMNH)

Distribution. Palaearctic Region (Belgium, Bulgaria, Netherlands, Romania, Sweden, Switzerland, Turkey, United Kingdom) (Noyes 2019). New species record for Finland.

\section{Polynema (Doriclytus) vitripenne (Foerster, 1847)}

= Polynema depressicollis Hellén, 1974: 20, syn. nov.

Material examined. $N$ : Espoo (6683:3370), 4.x.1982, M. Pulkkinen (1 , FMNH). Ta: Janakkala, Vapari (6758:3371), 15.x.2011, V. Vikberg (1 , $\mathrm{VVCT}$ )

Remarks. Polynema depressicollis is here synonymized with P. (Doriclytus) vitripenne (Foerster, 1847). Unfortunately, all specimens (of both sexes, unspecified in the original description other than by their localities) of the type series of $P$. depressicollis, including its holotype from Parikkala, are lost from FMNH. However, its original description (of the female sex) fits perfectly the redescription of that of $P$. (Doriclytus) vitripenne by TRIAPITSYN \& FIDALGo (2006), so there is no doubt about its identity, and therefore no neotype designation is necessary for $P$. depressicollis. Furthermore, HeLlÉN (1974) indicated that his $P$. depressicollis is the same species as the species from Denmark misidentified as $P$. euhariforme Haliday, 1833 by BAKKENDORF (1934), who illustrated it, and which was shown to be conspecific with $P$. (Doriclytus) vitripenne by TRIAPITSYN \& FIDALGO (2006) based on O. Bakkendorf's voucher specimens.

Distribution. Palaearctic Region (Belgium, Czech Republic, Denmark, Germany, Russia, Sweden, United Kingdom) (Triapitsyn \& Fidalgo 2006; Noyes 2019; SAMKoví et al. 2020). New species record for Finland.

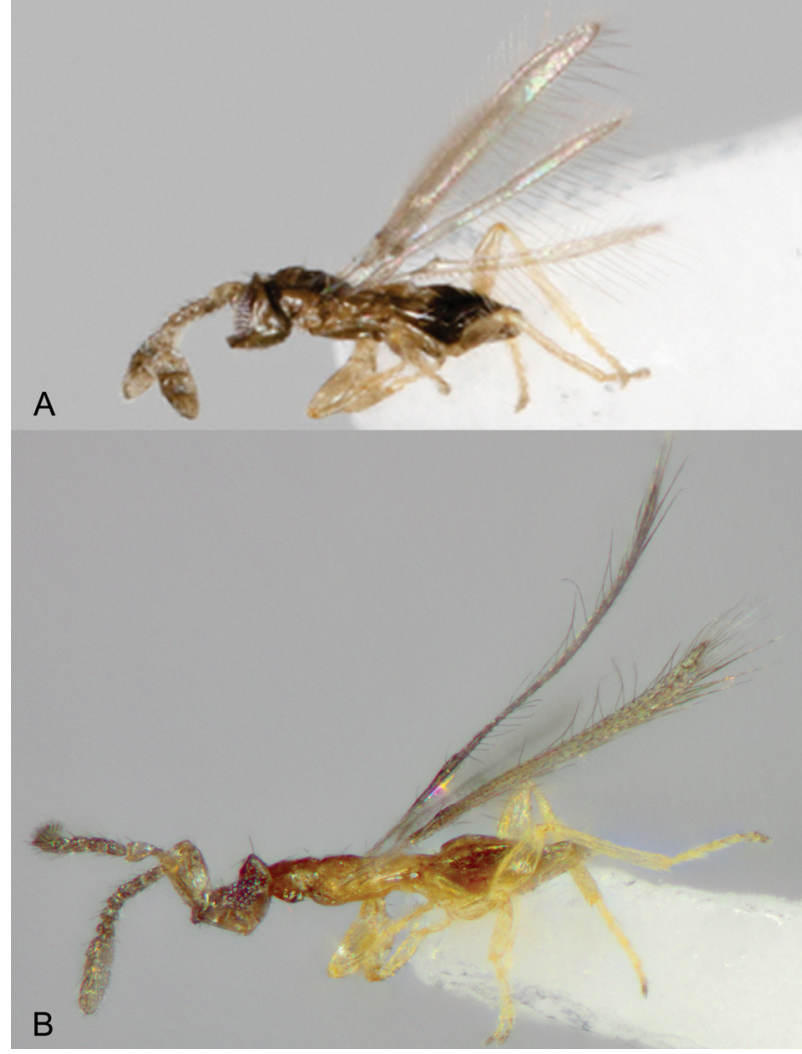

Fig. 16. Pseudocleruchus sp., habitus in lateral view (Janakkala, Tavastia Proper, Finland): A - female from Suurisuo; B - female from Kalpalinna.

\section{Pseudocleruchus sp.} (Fig. 16)

Material examined. Ta: Janakkala, V. Vikberg: Kalpalinna (6759:3369), 28.ix.2011 (1 9 (Fig. 16B); this specimen was unfortunately lost during shipping after being photographed at FMNH); Suurisuo (6766:3381), 18.vi.2009 (1 \& (Fig. 16A), CNC).

Remarks. According to John T. Huber (personal communication), who has examined and photographed the female from Suurisuo (SAmková et al. 2020), these specimens represent an undescribed species of the rare genus Pseudocleruchus Donev \& Huber, 2002, as it has a notably narrower fore wing compared with the one in the type species of the genus, $P$. triclavatus Donev \& Huber, 2002. We, however, are reluctant to describe it as a new taxon based on just one available specimen, which had been originally air-dried and thus shriveled (Fig. 16A), and then slide-mounted by J. T. Huber. We prefer to wait for more specimens to be collected to describe it properly. Distribution. Palaearctic Region (Finland).

\section{Stephanodes similis (Foerster, 1847)}

Material examined. Ta: Hämeenlinna, Ruununmylly (6766:8368), 2.vi.1977, V. Vikberg (1 +, VVCT)

Distribution. Palaearctic (Austria, Belgium, Bulgaria, Canary Islands, Croatia, Cyprus, Czech Republic, Denmark, Finland, France, Germany, Greece, Hungary, Italy, Kyrgyzstan, Madeira, Moldova, North Macedonia, Norway, Poland, Romania, Russia, Slovenia, Spain, Sweden, Switzerland, Turkey, Turkmenistan, Ukraine, United Kingdom), Afrotropical (Cape Verde, Democratic 
Republic of the Congo), Nearctic (Canada, USA), and Neotropical (Argentina, Paraguay) Regions (HELLÉN 1974; TRIAPITSYN \& BEREZOVSKIY 2002; KOPONEN \& TRIAPITSYN 2016; SCHUPPENHAUER \& TRIAPITSYN 2018; Noyes 2019; SAMKoví et al. 2020).

\section{Stethynium triclavatum Enock, 1909}

Material examined. $N$ : Nurmijärvi, 5.viii.1994, M. Koponen (1 $\widehat{\delta}$, FMNH). Ta: Janakkala, V. Vikberg: (6761:3371), 10.ix.1999 (1 q, VVCT); Kesiäisjoki, 13.viii.1995 (1 + , VVCT); Turenki, Rotary park, 4.ix.2014 (1 ㅇ, VVCT)

Remarks. The specimen collected in Janakkala on 10.ix.1999 was reported as a new species to the fauna of Finland at the monthly meeting of the Finnish Entomological Society on 17.ix.1999 by V. Vikberg but that communication was never published.

Distribution. Palaearctic (Austria, Belgium, Bulgaria, China, Czech Republic, Denmark, Egypt, France, Germany, Greece, Italy, Romania, Russia, Spain, Switzerland, United Kingdom), Nearctic (Bermuda, Canada, USA), Oceanian (Hawaiian Islands), and Oriental (India) Regions (BAQUERO \& JORDANA 2002; TRIAPITSYN 2002; NoYES 2019; SAMKOvá et al. 2020). New genus and species record for Finland.

\section{Checklist of Finnish Mymaridae}

Taxa new for Finnish fauna are marked by an asterisk $(*)$.

Alaptus Westwood, 1839

fusculus Walker, 1846 (TRIAPITSYN 2017)

= foersteri Soyka, 1939 (Hellén 1974, 1976)

minimus Westwood, 1839 (HelléN 1961b, 1966, 1974; TRIAPITSYN 2017)

pallidicornis Foerster, 1856 (a subsequent emendation of the original spelling pallidornis Foerster, 1856) (VIKBERG 1982; SiLfVERBERG 1986; TRIAPITSYN 2017) schmitzi Soyka, 1939 (TRIAPITSYN 2017)

stammeri Soyka, 1939 (TRIAPITSYN 2017)

terebrans Kryger, 1950 (TRIAPITSYN 2017)

Anagrus Haliday, 1833

Subgenus Anagrus Haliday, 1833

atomus (Linnaeus, 1767) (RAATIKAINEN 1962, 1967, 1970; HelléN 1966; ViKbERG 1982; SilfVERBERG 1986; FUSU 2013)

*avalae Soyka, 1956

*bakkendorfi Soyka, 1946

*ensifer Debauche, 1948

fennicus Soyka, 1956 (SOYKa 1956a; TRIAPITSYN \& BEREZOVSKIY 2004a; FUSU 2013).

incarnatus Haliday, 1833 ([RIMSKY-KORSAKOV 1917]; Wuorentaus 1917; Hellén 1947; Hellén 1974, as A. incarnatus or A. subfuscus Foerster, 1847; VIKBERG 1982; TRIAPITSYN \& BEREZOVSKIY 2004a; TRIAPITSYN 1997; FUSU 2013; TRIAPITSYN et al. 2018)

= breviphragma Soyka, 1956

= incarnatosimilis Soyka, 1956

*nigriceps (Smits van Burgst, 1914)

*obscurus Förster, 1861

*parvus Soyka, 1956

*subfuscus Foerster, 1847
*Subgenus Paranagrus Perkins, 1905

*optabilis (Perkins, 1905)

Anaphes Haliday, 1833

Subgenus Anaphes Haliday, 1833 (= fuscipennis species group)

crassipennis (Soyka, 1946) (SoYKA 1946, 1949; Hellén 1952, 1974; Fusu 2013)

= acutipennis (Soyka, 1949) (SoYKa 1949; Hellén 1952; FusU 2013; HUBER \& THURÓCZY 2018)

= fennicus (Soyka, 1955) (SOYKA 1955; HelLÉn 1956; Fusu 2013; Huber \& THURÓCZY 2018)

flavipes (Foerster, 1841) (HELLÉN 1974, 1976)

fuscipennis Haliday, 1833 (HELlÉN 1974, 1976)

= pratensis Foerster, 1847 (HeLlÉN 1974, 1976; KOPONEN \& VIKBERG 1984)

regulus Walker, 1846

= autumnalis Foerster, 1847 (HelLÉN 1974, 1976)

*stygius Debauche, 1948

Subgenus Patasson Walker, 1846 (= crassicornis species group)

diana (Girault, 1911)

= lameerei (Debauche, 1948) (HELLÉN 1974, 1976)

luna (Girault, 1948)

= brachygaster $($ Debauche, 1948) (HeLlÉN 1974, 1976; KOPONEN

\& ViKBERg 1984; HUBER \& ThURóCZY 2018)

= devillei (Debauche, 1948) (HeLlÉN 1974, 1976; Huber \&

THuRóczy 2018)

= euryale (Debauche, 1948) (HeLlÉN 1974, 1976; HuBER \& THuRóczy 2018)

silesicus (Soyka, 1946)

= calvescens (Debauche, 1948) (HeLLÉN 1974, 1976; HUBER \& THURócZy 2018)

Arescon Walker, 1846

= Neurotes Enock, 1914

dimidiatus (Curtis, 1832) (HELLÉN 1967, 1968, 1971, 1974, 1976; TRIAPITSYN \& BEREZOVSKIY 2003, 2004b)

iridescens (Enock, 1913) (KRYGER 1950; HELLÉN 1966, 1968, 1974; TRIAPITSYN \& BEREZOVSKIY 2003, 2004b)

Camptoptera Foerster, 1856

cardui (Foerster, 1856) (TRIAPITSYN 2014b)

= aula Debauche, 1948 (Koponen 2009)

*magna Soyka, 1946

papaveris Foerster, 1856 (HELLÉN 1974, 1976; KOPONEN 2009; TRIAPITSYN 2014b)

Cleruchus Enock, 1909

*megatrichus Novicky, 1965

pluteus Enock, 1909 (VIKBERG 1982; SILFVERBERG 1986; TRIAPITSYN 2014a)

*taktochno Triapitsyn, 2014

Cosmocomoidea Howard, 1908

atra (Foerster, 1841) (HELLÉN 1974, 1976, as Gonatocerus ater Foerster; TRIAPITSYN 2013, as Gonatocerus (Cosmocomoidea) ater Foerster)

*oxypygus (Foerster, 1856)

*tremulae (Bakkendorf, 1934) 
*Dicopus Enock, 1909

*minutissimus Enock, 1909

*moscovit Triapitsyn, 2015

\section{Erythmelus Enock, 1909}

Subgenus Erythmelus Enock, 1909

agilis (Enock, 1909) (HELLÉN 1968, 1971, 1974, 1976;

TRIAPITSYN 2003b)

dichromocnemus Novicky, 1953 (TRIAPITSYN et al. 2017)

flavovarius (Walker, 1846) (TRIAPITSYN 2003b)

= goochi Enock, 1909 (HeLLÉN 1967, 1968, 1971, 1974)

Subgenus Parallelaptera Enock, 1909

panis (Enock, 1909) (HELLÉN 1967, 1968, 1971, 1974; TRIAPITSYN 2003b)

Eustochus Haliday, 1833

Subgenus Caraphractus Walker, 1846, syn. nov. and stat. revid.

cinctus (Walker, 1846), comb. nov. ([RIMSKY-KORSAKOV 1917, 1925]; [HeLléN 1926]; HelléN 1947, 1974; TRIAPITSYN 2012)

= Polynema natans Lubbock, 1864 (PALMÉN 1881)

= Caraphractus favicollis Hellén, 1974 (Hellén 1974, 1976; TRIAPITSYN 2012; Fusu 2013)

Subgenus Eustochus Haliday, 1833

atripennis (Curtis, 1832) (VIKBERG 1982; SILFVERBERG 1986)

*koponeni Triapitsyn, sp. nov.

Gonatocerus Nees ab Esenbeck, 1834

*aegyptiacus Soyka, 1950

fuscicornis (Walker, 1846) (TRIAPITSYN 2013, as Gonatocerus (Gonatocerus) fuscicornis (Walker))

= sulphuripes Foerster, 1847 (HeLLÉN 1974, 1976)

longicornis Nees ab Esenbeck, 1834 (TRIAPITSYN 2003a; FUSU 2013; TRIAPITSYN 2013, as Gonatocerus (Gonatocerus) longicornis Nees ab Esenbeck) = terebrator $($ Foerster, 1847) (HelléN 1974, 1976)

pictus (Haliday, 1833) (HELLÉN 1974, 1976; TRIAPITSYN 2013, as Gonatocerus (Gonatocerus) pictus (Haliday))

Litus Haliday, 1833

cynipseus Haliday, 1833 (HelléN 1967, 1968, 1971, 1974; TRIAPITSYN \& BEREZOVSKIY 2004b)

Lymaenon Walker, 1846

*aureus (Girault, 1911)

= chrysis Debauche, 1948 (MatTHews 1986, as Gonatocerus chrysis (Debauche, 1948) but referring to Gonatocerus gracilentus Hellén, 1974)

gracilentus (Hellén, 1974), stat. rev. (HELLÉN 1974, 1976, as Gonatocerus gracilentus Hellén)

litoralis (Haliday, 1833) (HelléN 1974, 1976, as Gonatocerus litoralis (Haliday); Fusu 2013, as G. litoralis; TRIAPITSYN 2013, as Gonatocerus (Lymaenon) litoralis (Haliday))

= Gonatocerus pulchellus Hellén, 1974 (HelléN 1974, 1976; Matthews 1986)

*longior (Soyka, 1946)
Mymar Curtis, 1832

pulchellum Curtis, 1832 ([HACKMAN 1961]; HeLLÉN 1961a, 1974)

regale Enock, 1911 (HELLÉN 1974, 1976)

Ooctonus Haliday, 1833

hemipterus Haliday, 1833 (HELLÉN 1968, 1971, 1974; TRIAPITSYN 2010; Fusu 2013; KoPONEN et al. 2019) insignis Haliday, 1833 (HELLÉN 1974, 1976; TRIAPITSYN 2010; Fusu 2013; Koponen et al. 2019)

notatus Walker, 1846 (TRIAPITSYN 2010; FUSU 2013; KOPONEN et al. 2019)

= heterotomus Foerster, 1847 (HelléN 1974, 1976)

novickyi Soyka, 1950 (KoPONEN et al. 2019)

sublaevis Foerster, 1847 (KoPONEN et al. 2019)

$=$ dovrensis Solem \& Sveum, $1980($ VIKBERG 1982; SILFVERBERG 1986)

vulgatus Haliday, 1833 (HELLÉN 1967, 1968, 1971, 1974;

TRIAPITSYN 2010; Fusu 2013; KoPONEN et al. 2019)

Polynema Haliday, 1833

aequicoloratum (Soyka, 1950) (SOYKA 1950, 1956a; HelléN 1971; TRJAPITZIN 1978; Fusu 2013)

arcticum Soyka, 1956 (SoYKA 1956a; HelléN 1971; TRJAPITZIN 1978; FUSU 2013)

atratum Haliday, 1833 (HeLlÉN 1969, 1971, 1974)

auripedicellatum (Soyka, 1950) (SoYKA 1950, 1956a; HellÉn 1971; TRJAPITZIN 1978; FUSU 2013)

calceatiscapus (Soyka, 1950) (SOYKA 1950, 1956a; HellÉN 1971; TRJAPITZIN 1978; FUSU 2013)

euchariforme Haliday, 1833 (HELLÉN 1969, 1971, 1974)

fennicosimile (Soyka, 1950) (SOYKA 1950, 1956a; Hellén 1971; TRJAPITZIN 1978; FusU 2013)

fennicum Soyka, 1946 (SoYKa 1946; TRJAPITZIN 1978; FUSU 2013)

*flavipes Walker, 1846

fumipenne Walker, 1846 (HELLÉN 1962, 1966, 1974)

*fuscipes Haliday, 1833

gracile (Nees ab Esenbeck, 1834) (HELLÉN 1968, 1971, 1974)

= fuscipes auct. (HELLÉN 1969, 1971)

halidayi Debauche, 1948 (HeLlÉN 1969, 1971, 1974, 1976)

= valkenburgense auct. (HeLLÉN 1969, 1971)

laetum Foerster, 1847 (HELLÉN 1974)

neorectum Soyka, 1956 (SOYKA 1956a; HelléN 1971; TrJaPITZIN 1978; Fusu 2013)

nigriceps Soyka, 1956 (SoYKa 1956a; HelléN 1971; TRJAPITZIN 1978; FUSU 2013)

parvipennis Soyka, 1956 (SOYKA 1956a; HELLÉN 1971; TRJAPITZIN 1978; FusU 2013)

*pusilloides Debauche, 1948

pusillum Haliday, 1833 (Hellén 1969, 1971, 1974, 1976)

= atractoura auct. (HELLÉN 1969, 1971)

*valkenburgense Soyka, 1931

*vitripenne (Foerster, 1847)

= depressicollis Hellén, 1974, syn. nov. (HelléN 1974, 1976; Fusu 2013)

Pseudocleruchus Donev \& Huber, 2002

sp. (SAmKová et al. 2020) 
Stephanodes Enock, 1909

similis (Foerster, 1847) (HELLÉN 1967, 1968, 1971, 1974;

TRIAPITSYN \& BEREZOVSKIY 2002; FUSU 2013)

*Stethynium Enock, 1909

*triclavatum Enock, 1909

\section{Discussion}

Our current knowledge of the Finnish fauna of Mymaridae, comprising 85 named species in 19 genera (among them 2 genera, 1 subgenus, and 26 species representing new records for Finland) is dominated by the taxa which are commonly captured by sweeping. Indeed, the bulk of the specimens we have examined and identified is comprised of just a few widespread species such as Gonatocerus fuscicornis (Walker, 1846), Lymaenon litoralis (Haliday, 1833), Ooctonus hemipterus Haliday, 1833, and Polynema (Doriclytus) atratum Haliday, 1833, which are commonly collected on grassy vegetation in any northern European country. Yet, we are confident that the decades-long collecting efforts by two of us have managed to capture the majority of species of the family that occur in Finland, even though representation of the specimens of some genera in the collections (e.g., of Alaptus Westwood, 1839, Camptoptera Foerster, 1856, and some others) is rather limited. These would definitely be more abundant in Malaise trap samples which are yet to be processed for sorting out more of Finnish mymarids, or among newly collected material using this method. A few additional taxa can potentially be captured by other collecting methods such as yellow pan, flight intercept, light and pitfall traps, Berlese funnels and Winkler hanging extractors from soil, moss and leaf litter, rearing from known hosts and from bracket fungi, stems and leaves of aquatic plants, and from cones of coniferous trees, by sampling aerial plankton, canopy fogging, etc. However, even with that the overall diversity of the family in the country is not expected to exceed perhaps around 100 valid species in the 20 currently recognized genera, even when numerous specimens in the more diverse genera such as Anaphes and Polynema are properly identified. Also, four apparently undescribed species of Anagrus Haliday, 1833 have been recently recognized by the first author among the specimens collected in Finland by the second author; however, more material of these would be needed to properly describe them as new taxa. It also seems that all the mymarid genera that are likely to occur in Finland have been recorded, with the likely exception of the fairly rarely collected Macrocamptoptera Girault, 1910, as the current synonym (Herulia sundholmi Hedqvist, 1962) of one of its members, M. grangeri Soyka, 1961, was described from Sweden (near Tromtö, Förkärla, Blekinge) (HEDQvisT 1962, TRIAPITSYN 2012, TRIAPITSYN et al. 2020b).

Examination of the historically important fairyfly collection of W. Hellén in FMNH, specimens in which were all air-dried (and thus mostly shriveled) and card- or point-mounted (he did not make any slides), revealed that he generally correctly identified most genera and species that were more or less recognizable at that time. However, he definitely misidentified most of the species in the taxonomically difficult genera such as Anagrus, Anaphes and Polynema, and also some in Alaptus, Cosmocomoidea Howard, 1908 and Lymaenon Haliday, 1833. Species identification in these genera requires preparation of good quality microscopic slides in most cases, and males of many species of Anagrus, Lymaenon, and Polynema, and of most Anaphes species are currently not identifiable morphologically. For instance, at least four different species of Anagrus stand under the specimens identified by W. Hellén as Anagrus incarnatus Haliday, 1833 (including some true $A$. incarnatus). Particularly, HelléN (1974) misidentified some Camptoptera magna Soyka, 1946 as C. papaveris Foerster, 1856; Gonatocerus aegyptiacus Soyka, 1950, Gonatocerus fuscicornis, Gonatocerus spp. and a Lymaenon sp. as Gonatocerus pictus (Haliday, 1833); and Lymaenon litoralis and a Lymaenon sp. as Gonatocerus ater Foerster, 1841 (now Cosmocomoidea atra (Foerster)). Because none of the specimens in FMNH identified as Gonatocerus thyrides (Debauche, 1948) (HelléN 1974, 1976) belong to the true Lymaenon thyrides, this species is excluded from the checklist of properly recorded Finnish Mymaridae; however, the likelihood that it occurs in Finland is very high. Specimens misidentified by W. Hellén as Gonatocerus thyrides in fact belong to Cosmocomoidea atra, Cosmocomoidea sp., and Lymaenon litoralis. Likewise, none of the specimens from Finland and the former Finnish territories in Leningrad oblast of Russia, identified as Gonatocerus novickyi Soyka, 1946 (Hellén 1974, 1976), belong to the true Lymaenon novickyi, so this species is also excluded from the checklist above; they are a mixture of several other species of Gonatocerini.

\section{Acknowledgments}

We thank Juho Paukkunen (FMNH) for kind assistance with this project and the loans of specimens to the first author, Vladimir V. Berezovskiy (UCRC) for making excellent slide mounts of selected specimens, and also Petr Kment (Editor-in-Chief of Acta Entomologica Musei Nationalis Pragae) for many useful edits and suggestions. Jochen Müller and Matthias Hartmann (NMEG) provided access to the specimens from Germany, and John T. Huber (CNC) shared valuable information on some of the taxa. This study received funding from the Research Programme of Deficiently Known and Threatened Forest Species 2009-2016 (PUTTE) of the Finnish Ministry of the Environment (grant to G. Várkonyi).

\section{References}

AHTI T., HÄMET-AHTI L. \& JALAS J. 1968: Vegetation zones and their sections in northwestern Europe. Annales Botanici Fennici 5: $169-211$.

AISHAN Z., TRIAPITSYN S. V. \& HU H.-Y. 2020: A review of the Chinese species of Lymaenon (Hymenoptera: Mymaridae), with description of six new species. Zootaxa 4834(4): 573-595.

ANWAR P. T., ZEYA S. B. \& VEENAKUMARI L. 2020: Fairyfly genus Camptoptera Foerster (Hymenoptera: Chalcidoidea: Mymaridae) in India and Sri Lanka with descriptions of eleven new species. Zoologica 165: 1-89.

BAI H.-F., JIN X.-X. \& LI C.-D. 2015: A taxonomic study of Ooctonus (Hymenoptera, Mymaridae) from Heilongjiang, China. ZooKeys 479: $25-36$. 
BAKKENDORF O. 1934: Biological investigations on some Danish hymenopterous egg-parasites, especially in homopterous and heteropterous eggs, with taxonomic remarks and descriptions of new species. Entomologiske Meddelelser 19(1) [1933]: 1-135.

BAQUERO E. \& JORDANA R. 2002: Contribution to the knowledge of the family Mymaridae Haliday (Hymenoptera: Chalcidoidea) in Navarra, North of Iberian peninsula. Boletín de la Asociación Española de Entomología 26(3-4): 75-91.

CHIAPPINI E. 1989: Review of the European species of the genus Anagrus Haliday (Hymenoptera Chalcidoidea). Bollettino di Zoologia Agraria e di Bachicoltura, Serie II 21: 85-119.

DEBAUCHE H. R. 1948: Etude sur les Mymarommidae et les Mymaridae de la Belgique (Hymenoptera Chalcidoidea). Mémoires du Musée Royal d'Histoire Naturelle de Belgique 108: 1-248.

FOERSTER A. 1847: Ueber die Familie der Mymariden. Linnaea Entomologica 2: 195-233.

FUSU L. 2013: Mymaridae. In: MITROIU M.-D. (ed.): Fauna Europaea. Version 2.6.2. Available at: https://fauna-eu.org/cdm_dataportal/taxon/ e1f3c80d-b0e9-4e22-b393-024f8aebcfeb

GIBSON G. A. P. 1997: Chapter 2. Morphology and terminology. Pp. 16-44. In: GIBSON G. A. P., HUBER J. T. \& WOOLLEY J. B. (eds): Annotated keys to the genera of Nearctic Chalcidoidea (Hymenoptera). NRC Research Press, Ottawa, 794 pp.

HACKMAN W. 1961: Helsingin Yliopiston Hyönteistieteellisen museon kokoelmien kasvu toimintavuonna 1959-60. Samlingarnas tillväxt vid Helsingfors Universitetets Entomologiska museum under verksamhetsåret 1959-1960. [Growth of the collections at the University of Helsinki Entomological Museum during fiscal year 1959-1960]. Memoranda Societatis pro Fauna et Flora Fennica 36: 128-133 (in Finnish and Swedish).

HEDQVIST K. J. 1962: Herulia gen. n. sundholmi sp. n., eine neue Mymaridengattung mit einer neuen Art von Schweden (Hym. Chalcidoidea, Mymaridae). Opuscula Entomologica (Lund) 27: 103-105.

HEIKINHEIMO O. \& RAATIKAINEN M. 1971: Paikan ilmoittaminen Suomesta talletetuissa biologisissa aineistoissa. [Reporting on location data of biological materials deposited from Finland]. Annales Entomologici Fennici (Suomen Hyönteistieteellinen Aikakauskirja) 37(1a): 1-27 (in Finnish).

HELLÉN W. 1926: Verzeichnis der in den Jahren 1921-1925 für die Fauna Finlands neuhinzugekommenen Insektenarten. Notulae Entomologicae 6: $90-96$.

HELLÉN W. 1947: Verzeichnis der in den Jahren 1941-1945 für die Fauna Finnlands neuhinzugekommenen Insektenarten. Notulae Entomologicae 26: $122-142$.

HELLÉN W. 1952: Verzeichnis der in den Jahren 1946-1950 für die Fauna Finnlands neuhinzugekommenen Insektenarten. Notulae Entomologicae 32: 59-80.

HELLÉN W. 1956: Verzeichnis der in den Jahren 1951-1955 für die Fauna Finnlands neuhinzugekommenen Insektenarten. Notulae Entomologicae 36: $33-50$.

HELLÉN W. 1961a: Mymar pulchellum (Mymaridae). Notulae Entomologicae 40: 154.

HELLÉN W. 1961b: Alaptus minimus (Mymaridae). Notulae Entomologicae 41: 104.

HELLÉN W. 1962: Polynema fumipennis (Mymaridae). Notulae Entomologicae 42: 31.

HELLÉN W. 1966: Verzeichnis der in den Jahren 1961-1965 für die Fauna Finnlands neuhinzugekommenen Insektenarten. Notulae Entomologicae 46: $65-86$

HELLÉN W. 1967: 6 för faunan nya parasitsteklar av fam. Mymaridae. [6 new country records of parasitic wasps of the family Mymaridae] Notulae Entomologicae 47: 160 (in Swedish).

HELLÉN W. 1968: För Finlands fauna nya Mymaridae (Hymenoptera, Chalcididae). [Mymaridae (Hymenoptera, Chalcididae) new for the Finnish fauna]. Notulae Entomologicae 48: 34 (in Swedish).

HELLÉN W. 1969: 7 för landet nya arter av stekelfamiljen Mymaridae. [7 new species records for the country of the parasitic wasp family Mymaridae]. Notulae Entomologicae 49: 287 (in Swedish).

HELLÉN W. 1971: Verzeichnis der in den Jahren 1966-1970 für die Fauna Finnlands neuhinzugekommenen Insektenarten. Notulae Entomologicae 51: 73-91.
HELLÉN W. 1974: Die Mymariden Finnlands (Hymenoptera: Chalcidoidea). Fauna Fennica 25: 1-30.

HELLÉN W. E. 1976: Verzeichnis der in den Jahren 1971-1975 für die Fauna Finnlands neu hinzugekommenen Insektenarten. Notulae Entomologicae 56: 109-120.

HUBER J. T. 2015: World reclassification of the Gonatocerus group of genera (Hymenoptera: Mymaridae). Zootaxa 3967(1): 1-184.

HUBER J. T. \& BAQUERO E. 2007: Review of Eustochus, a rarely collected genus of Mymaridae (Hymenoptera). Proceedings of the Entomological Society of Ontario 138: 3-31.

HUBER J. T. \& THURÓCZY C. 2018: Review of Anaphes Haliday (Hymenoptera: Mymaridae) with key to species in Europe and a world catalogue. Zootaxa 4376(1): 1-104.

HULDÉN L. 1984: Observations on an egg parasite of Cicadella viridis (L.) (Homoptera, Auchenorrhyncha). Notulae Entomologicae 64: 84-85.

KHALAIM A. I. \& VÁRKONYI G. 2018: A review of Tersilochinae (Hymenoptera: Ichneumonidae) of Finland. Part 1: taxonomy. Zootaxa 4369(2): 151-185.

KOPONEN M. 2009: Toinen Camptoptera-laji Suomesta (Hymenoptera, Mymaridae). [Second Camptoptera species from Finland]. Sahlbergia 15(1): 1 (in Finnish).

KOPONEN M. \& TRIAPITSYN S. V. 2016: New records of Mymaridae (Hymenoptera, Chalcidoidea) from the Canary Islands and Madeira. Bocagiana 243: 1-4.

KOPONEN M., TRIAPITSYN S. V. \& VIKBERG V. 2019: Report on Ooctonus (Hymenoptera: Mymaridae) of Finland, with additional new records from some other European countries. Sahlbergia 24(2) (2018): 14-24.

KOPONEN M. \& VIKBERG V. 1984: Parasitic wasp (Hymenoptera, Parasitica) of Inari Lapland, excluding Ichneumonidae. Kevo Notes 7: 101-113.

KRYGER J. P. 1950: The European Mymaridae. Entomologiske Meddelelser 26: 1-97.

MATTHEWS M. J. 1986: The British species of Gonatocerus Nees (Hymenoptera: Mymaridae), egg parasitoids of Homoptera. Systematic Entomology 11: 213-229.

NOYES J. S. 2019: Universal Chalcidoidea Database. WWW publication. The Natural History Museum, London: https:/www.nhm.ac.uk/ our-science/data/chalcidoids/database/ (last accessed 1 October 2020).

PALMÉN J. A. 1881: Polynema natans Lubb. Meddelanden af Societatis pro Fauna et Flora Fennica 6: 206.

PRICOP E. 2013: Identification key to European genera of the Mymaridae (Hymenoptera: Chalcidoidea), with additional notes. ELBA Bioflux 5(1): 69-81.

PRICOP E. \& MOGLAN I. 2016: First record of the rare Mymarid genus Eustochus Haliday (Hymenoptera: Mymaridae) from Romania, with notes on biology. North-Western Journal of Zoology 12(2): 377-382.

RAATIKAINEN M. 1962: Hymenoptera species occurring in stems of spring wheat and the damage caused by them to wheat crops in Finland. Annales Agriculturae Fenniae 1: 217-225.

RAATIKAINEN M. 1967: Bionomics, enemies and population dynamics of Javesella pellucida (F.) (Hom., Delphacidae). Annales Agriculturae Fenniae 6 (Supplement 2): 1-149.

RAATIKAINEN M. 1970: Ecology and fluctuations in abundance of Megadelphax sordidula (Stål) (Hom., Delphacidae). Annales Agriculturae Fenniae 9: 315-324.

RIMSKY-KORSAKOV M. N. 1917: K faune vodnykh naezdnikov Rossii. [To the fauna of Russian aquatic parasitic Hymenoptera]. [Protocols of meetings of the Russian Entomological Society for 1916; meeting for $8^{\text {th }}$ November 1916]. Russkoe Entomologicheskoe Obozrenie (Revue Russe d'Entomologie) 16(3-4) [1916]: LXVII-LXVIII (in Russian).

RIMSKY-KORSAKOV M. N. 1925: O vodnykh naezdnikakh roda Caraphractus Haliday (S 14 risunkami). [On the aquatic parasitoid wasps from the genus Caraphractus Haliday (With 14 drawings)]. Trudy Leningradskogo Obshchestva Estestvoispytateley, Otdelenie Zoologii i Fiziologii [Leningrad] 54(2): 97-111 (in Russian).

SAMKOVÁ A., JANŠTA P. \& HUBER J. T. 2020: Illustrated key to European genera, subgenera and species groups of Mymaridae (Hymenoptera), with new records for the Czech Republic. Zootaxa 4722(3): 201-233. 
SCHAUFF M. E. 1984: The Holarctic genera of Mymaridae (Hymenoptera: Chalcidoidea). Memoirs of the Entomological Society of Washington 12: 1-67.

SCHUPPENHAUER M. M. \& TRIAPITSYN S. V. 2018: Contribution to the taxonomy of Polynema Haliday, 1833 and Stephanodes Enock, 1909 (Hymenoptera: Mymaridae) of Sweden. Entomologisk Tidskrift 139: $159-183$.

SILFVERBERG H. 1986: Additions to the Finnish insect fauna during the years 1981-1985. Notulae Entomologicae 66: 131-152.

SOYKA W. 1946: Revision einiger Mymridengattungen [sic]. Zentralblatt für das Gesamtgebiet der Entomologie 1(2): 33-40.

SOYKA W. 1949: Monographie der Mymar-Gruppe, mit den Gattungen Mymar Curtis, Synanaphes Soyka, Ferrierella Soyka, Anaphoidea Girault, Hofenederia Soyka, Fulmekiella Soyka und Yungaburra Girault. (Hymenoptera, Chalcidoidea, Mymaridae). Revista Entomologica (Rio de Janeiro) 20: 301-422.

SOYKA W. 1950: Neue Arten der Gattung Novickyella Soyka. Entomologisches Nachrichtenblatt (Burgdorf) 4(1): 14-34

SOYKA W. 1955: Neue Revision der Gattung Mymar Curtis (Mymaridae, Chalcidoidea, Hymenoptera). Mitteilungen der Münchner Entomologischen Gesellschaft 44-45: 460-475.

SOYKA W. 1956a: Monographie der Polynemagruppe. Abhandlungen der Zoologisch-Botanischen Gesellschaft in Wien 19: 1-115.

SOYKA W. 1956b: Überblick über das genus Anagrus Haliday (Alaptidae-Mymaridae, Chalcidoidea, Hymenoptera). Entomologisches Nachrichtenblatt Österreichischer und Schweizer Entomologen 7(2) [1955]: 23-26.

TRIAPITSYN S. V. 1997: The genus Anagrus (Hymenoptera: Mymaridae) in America south of the United States: a review. Ceiba 38(1): $1-12$.

TRIAPITSYN S. V. 1998: The H. R. Debauche collection of Anagrus (Hymenoptera: Mymaridae): an annotated catalog. Bulletin and Annales de la Société Royale Belge d'Entomologie 134: 139-146.

TRIAPITSYN S. V. 2002: Review of the Mymaridae (Hymenoptera, Chalcidoidea) of Primorskii Krai: genera Cleruchus Enock and Stethynium Enock. Far Eastern Entomologist 122: 1-13.

TRIAPITSYN S. V. 2003a: A note on the status of Gonatocerus cicadellae Nikolskaja, 1951 (Hymenoptera: Mymaridae). Russian Entomological Journal 12(2): 211-212.

TRIAPITSYN S. V. 2003b: Review of the Mymaridae (Hymenoptera, Chalcidoidea) of Primorskii krai: genus Erythmelus Enock, with taxonomic notes on some extralimital species. Far Eastern Entomologist 126: 1-44.

TRIAPITSYN S. V. 2010: Revision of the Palaearctic species and review of the Oriental species of Ooctonus (Hymenoptera: Mymaridae), with notes on extralimital taxa. Zootaxa 2381: 1-74.

TRIAPITSYN S. V. 2012: Taxonomic notes on Caraphractus (Hymenoptera: Mymaridae). Sahlbergia 17(2) [2011]: 20-29.

TRIAPITSYN S. V. 2013: Review of Gonatocerus (Hymenoptera: Mymaridae) in the Palaearctic region, with notes on extralimital distributions. Zootaxa 3644: 1-178.

TRIAPITSYN S. V. 2014a: Review of the Palaearctic species of Cleruchus Enock (Hymenoptera: Mymaridae). Far Eastern Entomologist 274: 1-59.

TRIAPITSYN S. V. 2014b: Revision of the genus Camptoptera Foerster (Hymenoptera: Mymaridae) in the Palaearctic region, with taxonomic notes on some extralimital species. Far Eastern Entomologist 285: $1-85$.

TRIAPITSYN S. V. 2015a: New records of Eulophidae, Mymaridae, Pteromalidae, and Tetracampidae (Hymenoptera: Chalcidoidea) from Russia, with annotations and description of a new species of Dicopus Enock. Far Eastern Entomologist 292: 1-12.

TRIAPITSYN S. V. 2015b: Taxonomy of the genus Anagrus Haliday (Hymenoptera: Mymaridae) of the world: an annotated key to the described species, discussion of the remaining problems, and a checklist. Acta Zoológica Lilloana 59(1-2): 3-50.

TRIAPITSYN S. V. 2017: Revision of Alaptus (Hymenoptera: Mymaridae) in the Holarctic region, with taxonomic notes on some extralimital species. Zootaxa 4279(1): 1-92.
TRIAPITSYN S. V. 2018: An annotated checklist of Mymaridae (Hymenoptera: Chalcidoidea) in Taiwan, with descriptions of five new species. Journal of Taiwan Agricultural Research 67(2): 113-165.

TRIAPITSYN S. V., ADACHI-HAGIMORI T., RUGMAN-JONES P. F., KADO N., SAWAMURA N. \& NARAI Y. 2020a: Egg parasitoids of Arboridia apicalis (Nawa, 1913) (Hemiptera, Cicadellidae), a leafhopper pest of grapevines in Japan, with description of a new species of Anagrus Haliday, 1833 (Hymenoptera, Mymaridae). ZooKeys 945: 129-152.

TRIAPITSYN S. V. \& BEREZOVSKIY V. V. 2002: Review of the Mymaridae (Hymenoptera, Chalcidoidea) of Primorskii krai: genera Chaetomymar Ogloblin, Himopolynema Taguchi, and Stephanodes Enock. Far Eastern Entomologist 110: 1-11.

TRIAPITSYN S. V. \& BEREZOVSKIY V. V. 2003: Review of the Mymaridae (Hymenoptera, Chalcidoidea) of Primorskii krai: genera Arescon Walker and Dicopomorpha Ogloblin. Far Eastern Entomologist 124: 1-15.

TRIAPITSYN S. V. \& BEREZOVSKIY V. V. 2004a: Review of the genus Anagrus Haliday, 1833 (Hymenoptera: Mymaridae) in Russia, with notes on some extralimital species. Far Eastern Entomologist 139: $1-36$.

TRIAPITSYN S. V. \& BEREZOVSKIY V. V. 2004b: Review of the genus Litus Haliday, 1833 in the Holarctic and Oriental regions, with notes on the Palaearctic species of Arescon Walker, 1846 (Hymenoptera: Mymaridae). Far Eastern Entomologist 141: 1-24.

TRIAPITSYN S. V., BEREZOVSKIY V. V., HODDLE M. S. \& MORSE J. G. 2007: A review of the Nearctic species of Erythmelus (Hymenoptera: Mymaridae), with a key and new additions to the New World fauna. Zootaxa 1641: 1-64.

TRIAPITSYN S. V., BEREZOVSKIY V. V. \& JAŁOSZYŃSKI P. 2017: Redescription of Erythmelus dichromocnemus Novicky, 1953 stat. rev. (Hymenoptera, Mymaridae) and a new synonymy. Polish Journal of Entomology 86(2): 181-191.

TRIAPITSYN S. V., DOMINGUEZ C., HUBER J. T., JAPOSHVILI G. \& HERATY J. M. 2020b: Morphological and molecular separation between Macrocamptoptera grangeri Soyka and M. metotarsa (Girault) (Hymenoptera: Mymaridae). Journal of Natural History 54(9-12): 585-596.

TRIAPITSYN S. V. \& FIDALGO P. 2006: Definition of Doriclytus, stat. rev. as a subgenus of Polynema and redescription of its type species, P. (Doriclytus) vitripenne (Hymenoptera: Mymaridae). Zootaxa 1362: 55-68.

TRIAPITSYN S. V. \& HUBER J. T. 2000: 51. Sem. Mymaridae - mymaridy. [Fam. Mymaridae - mymarids]. Pp. 603-614. In: LEHR P. A. (chief ed.): Opredeliteli nasekomykh Dal'nego Vostoka Rossii v shesti tomakh. [Keys to the insects of Russian Far East in six volumes]. Vol. IV. Neuropteroidea, Mecoptera, Hymenoptera, Part 4. [LELEJ A. S. (responsible ed.), KUPIANSKAYA A. N., NEMKOV P. G. \& KHOLIN S. K. (eds)]. Dal'nauka, Vladivostok, 651 pp (in Russian).

TRIAPITSYN S. V., RUGMAN-JONES P. F., TRETIAKOV P. S., SHIH H.-T. \& HUANG S.-H. 2018: New synonymies in the Anagrus incarnatus Haliday 'species complex' (Hymenoptera: Mymaridae) including a common parasitoid of economically important planthopper (Hemiptera: Delphacidae) pests of rice in Asia. Journal of Natural History 52(43-44): 2795-2822.

TRJAPITZIN V. A. 1978: Sem. Mymaridae - mymaridy. 18. [Fam. Mymaridae - mymarids]. Pp. 516-538. In: MEDVEDEV G. S. (chief ed.): Opredeliteli nasekomykh evropeyskoy chasti SSSR. [Keys to the insects of the European part of the USSR]. Vol. III. Hymenoptera, Part 2 [TRJAPITZIN V. A. (ed.)]. Nauka, Leningrad division, Leningrad, 758 pp (in Russian).

VIKBERG V. 1982: Additions to the chalcid fauna of Finland (Hymenoptera, Chalcidoidea). Notulae Entomologicae 62: 129-142.

WUORENTAUS Y. 1917: [Anagrus subfuscus Först.]. Meddelanden af Societatis pro Fauna et Flora Fennica 43: 32 (in Finnish). 
